Institute for Research on Poverty

Discussion Paper no. 1161-98

\title{
Do Attitudes and Personality Characteristics Affect Socioeconomic Outcomes? The Case of Welfare Use by Young Women
}

\author{
Robert Plotnick \\ Graduate School of Public Affairs and School of Social Work \\ University of Washington \\ E-mail: plotnick@u.washington.edu \\ Marieka Klawitter \\ Graduate School of Public Affairs \\ University of Washington \\ E-mail: marieka@u.washington.edu \\ Mark Edwards \\ Department of Sociology \\ Oregon State University
}

April 1998

This study was supported in part by the University of Washington Royalty Research Fund and the Social Policy Research Centre, University of New South Wales. We thank Yuen Huo, Paul LePore, Margaret O'Brien-Strain, Gene Smolensky, Maureen Waller, and seminar participants at the Public Policy Institute of California and the University of Washington for their comments.

IRP publications (discussion papers, special reports, and the newsletter Focus) are now available on the Internet. The IRP Web site can be accessed at the following address: http://www.ssc.wisc.edu/irp/ 


\begin{abstract}
We develop and estimate a model of social-psychological determinants of entry to the Aid to Families with Dependent Children (AFDC) program, the primary cash welfare program in the United States for 60 years until replaced in 1996. The structural model holds that attitudes and personality characteristics influence a woman's likelihood of becoming demographically and financially eligible for welfare and her willingness to bear the stigma of receiving benefits. These factors, in turn, affect the likelihood of actually going on welfare. We test for a relationship between social-psychological variables and welfare participation using data from the youngest cohorts of women in the National Longitudinal Survey of Youth. We estimate logit models of the probability of ever participating in AFDC up to age 25 and hazard models of the timing until first use of AFDC. The attitudes and personality characteristics in the empirical model are self-esteem, locus of control, attitudes toward school, attitudes toward women's work and family roles, commitment to work, and aversion to accepting public assistance. We find strong associations between welfare use and several attitudes and personality characteristics, but most of the associations are not robust to the inclusion of exogenous personal and family background characteristics. Consistent, strong evidence suggests that more positive attitudes toward school lower the likelihood of using welfare and increase duration until first receipt.
\end{abstract}




\section{Do Attitudes and Personality Characteristics Affect Socioeconomic Outcomes? The Case of Welfare Use by Young Women}

\section{INTRODUCTION}

Recent public debate about welfare reform has implicitly and explicitly embraced one of the oldest questions of social science. Are individuals mainly responsible for the negative social situations they may find themselves in (on welfare, poor, unmarried and a teen mother, unemployed, incarcerated, etc.) because of their own values and choices? Or are their situations mostly the product of larger social forces (business cycles, racism, structural unemployment, the occupational structure, school systems, parental characteristics) well beyond the control of any individual? The American public and its politicians tend to explain welfare use and other problematic or dysfunctional behaviors (as well as success) as the products of individual values and character attributes (Wilson, 1996, chap. 6). On both philosophical and empirical grounds, sociologists have generally favored structural explanations to the question of responsibility. They have also assembled strong evidence that parental and other family background characteristics beyond individual control play central roles in determining socioeconomic attainment.

But if the old adage is true, that conservatives are liberals who have been mugged, then it may also be true that ardent structuralists with pregnant teenage daughters are likely to begin explaining such behavior in individualist terms. That is, despite the shaky evidence to date, we social scientists still suspect that attitudes, values, and character "matter" for explaining social behaviors and socioeconomic outcomes. ${ }^{1}$ This study attempts to isolate the effects of several attitudes and personality characteristics on one important behavior-initial entry into welfare use.

Our inclusion of social-psychological variables in models of a socioeconomic outcome is not novel. But because we have significantly better data than have been available in most earlier studies, we 
are able to speak to the broad individualist/structuralist responsibility question in the context of a specific, highly visible, controversial outcome.

Our study also helps fill a gap in the literature on determinants of welfare use. Most research has examined the nature and determinants of exits from welfare. Current debate is largely focused on finding policies that speed exit via job training and education programs or enhanced incentives for work, or by imposing time limits on the receipt of benefits. Better knowledge of the determinants of entry might help shape interventions that could also have a substantial impact on AFDC caseloads, costs, and long-term use. Yet hardly any research has been done on the determinants of entry onto welfare.

In this study, we develop and estimate a model of social-psychological determinants of entry to the Aid to Families with Dependent Children (AFDC) program, the primary cash welfare program in the United States for 60 years until replaced by Temporary Assistance for Needy Families in 1996. We use data from the youngest cohorts of women in the National Longitudinal Survey of Youth (NLSY) to construct AFDC histories starting at age 15. We model the process of initially enrolling in (or avoiding) AFDC as a function of attitudes and personality characteristics as well as other variables—-such as personal and family background characteristics, AFDC program parameters, and local social and economic conditions - that might also affect decisions of young women to enroll. The attitude and personality variables include self-esteem, locus of control, attitudes toward school, attitudes toward women's work and family roles, commitment to work, and attitudes about accepting public assistance. We present results for the full sample and for subgroups defined by race and ethnicity and by poverty status.

Attitudes and personality characteristics are measured at relatively early ages, prior to AFDC participation and prior to demographic and economic events closely linked with AFDC participation, such as teen pregnancy and birth, finding and losing jobs, and divorce, all of which may affect selfesteem, locus of control, and attitudes. Consequently, we think it more likely that we have identified the 
exogenous effects of these characteristics on welfare participation and not confounded them with the effects of welfare participation on these same characteristics. If so, we avoid the confusion over causal direction that has plagued other studies of the relationship between social-psychological characteristics and socioeconomic outcomes.

We find strong associations between welfare use and several attitudes and personality characteristics, but most of the associations are not robust to the inclusion of exogenous personal and family background characteristics. Consistent, strong evidence suggests that more positive attitudes toward school lower the likelihood of using welfare and delay entry into welfare.

\section{RELATED STUDIES OF WELFARE USE AND DYNAMICS}

Past examinations of welfare use have included studies of entry to and exit from AFDC and other needs-tested programs, welfare re-entry, welfare use by young adults, and cross-section analyses of welfare participation. Most of this research has been based on an economic perspective in which the decision to participate in a welfare program and, by extension, entry to and exit from welfare are functions of the benefits of receiving aid and the alternatives to it (see Moffitt, 1992, for a review and references). The net benefits of aid depend on the amount of aid available, the process and costs of applying for aid, and the possible stigma attached to receiving it. Employment opportunities and income from a spouse or partner provide alternatives to welfare. The studies control for a range of individual characteristics that are usually interpreted as indicators of "tastes" or earnings ability. Some sociological

analyses take a similar approach, combined with a life course perspective (Harris, 1993, 1996, 1997), while others (Rank, 1986; McLanahan, 1988) focus on the role of family structure.

With the exception of Harris (1997), neither economic nor sociological studies analyze whether attitudes and personality characteristics affect the likelihood of going on welfare or the time until a spell of welfare begins. The few other studies that do investigate attitudes and personality characteristics either 
analyze whether they affect exit from AFDC or analyze whether being on welfare affects these characteristics, rather than focusing on the causal direction of interest here.

Six published multivariate analyses based on micro-data examine entry onto AFDC. ${ }^{2}$ Data sets used in early studies by Hutchens (1981) and Plotnick (1983) do not allow them to distinguish first spells of welfare from later spells. Four studies model entry into the first spell of welfare use (McLanahan, 1988; Gottschalk and Moffitt, 1994; Gottschalk, 1996; Harris, 1997). Only Harris (1997) considers any role for attitudes and personality variables. Her analysis of the small "Baltimore sample" of black teenage mothers finds that mothers with high educational aspirations are much less likely to enter welfare than those with low aspirations.

The literature on welfare re-entry analyzes determinants of entry into a second or higher-order spell of welfare (Bane and Ellwood, 1994; Blank and Ruggles, 1994; Brandon, 1995; Gleason, Rangarajan, and Schochet, n.d.; Harris, 1996; Lane and Stevens, 1995). None of the re-entry studies examines attitudes and personality variables. ${ }^{3}$

Three contributions to the literature on children's social attainment analyze the determinants of whether a woman uses welfare at some time as a teenager or young adult, rather than the dynamics of such use. Duncan and Hoffman (1990) and Haveman and Wolfe (1994) examine the joint outcome of becoming a teenage unwed mother and going on AFDC. Neither study examines attitudes and personality variables. Solon et al. (1988) analyze whether a woman ever received some form of income-tested aid between the time she left home and age 27 . The study focuses on determining sibling and intergenerational correlations in welfare use but does not assess how specific individual and family characteristics affect the estimated correlations.

Studies of who participates in welfare at a point in time consistently find that the benefit structure and expected wages are significant predictors of participation (Moffitt, 1992). This pattern supports the economic theory that welfare participation is a utility-maximizing choice based on labor 
market considerations. Since these studies apply cross-section methods to broad samples of female heads of families, they provide only indirect information on determinants of initial welfare use among young women. None of these studies investigates whether attitude and personality characteristics also affect participation, holding constant benefits and other economic considerations.

Most research on the dynamics of welfare participation looks at the nature and determinants of exit. ${ }^{4}$ This stream of research generally finds that the duration of welfare spells tends to be longer for women who are younger, disabled, or black; who have never married; who have more children, younger children, low expected wages, poor education, or little work experience; and who live where AFDC benefits are higher and labor market conditions are poorer.

Only three studies provide direct evidence of the effects of attitude and personality variables on welfare use. Goodwin (1983) analyzes factors that affected whether AFDC recipients in a work incentive program in 1978 exited AFDC through work one year later. A measure of general self-confidence (a mixture of items related to self-esteem and locus of control) was not related to exiting. Women with greater expectations of becoming independent were more likely to exit. O'Neill, Bassi, and Wolf (1987) analyze welfare spells in the National Longitudinal Survey (NLS) and find that women with more internal locus of control are more likely to exit AFDC via earnings, but are not more likely to exit via marriage. The study can only measure spells on an annual basis and does not provide findings for other attitude and personality variables. Another study of the NLS (Dolinsky, Caputo, and O'Kane, 1989) analyzes number of years of reported welfare receipt, rather than spell length. It reports that locus of control and attitudes toward women's family roles, measured in 1972 or 1973, are not significantly related to years of receipt during 1976-1979, but women with greater "family orientation" receive welfare in fewer years.

None of these three studies examines social-psychological determinants of entry into AFDC. While all three use attitude and personality variables measured prior to the outcomes they analyze, none 
have data that allows them to tell if an episode of welfare they analyze is a respondent's initial spell of welfare. Since, at least for some sample members, earlier experience with welfare may have affected these variables, the exogeneity of these variables may be suspect.

Two important papers analyze the reverse causal path—namely, the effect of receiving welfare on measures of psychosocial well-being. Using the Panel Study of Income Dynamics (PSID), NicholsCasebolt (1986) creates a one-item measure of self-esteem and a three-item measure of "personal competence," which closely resembles locus of control. Cross-section regression models show that welfare receipt reduces reported personal competence for white and black women. (The models do not attempt to adjust for possible reverse causality.) Panel models that relate changes in the measures to changes in welfare status confirm that going on AFDC reduces psychological well-being for blacks, but they show insignificant effects for whites. A careful study of white women in the NLSY (Elliott, 1996) reports that the number of years on welfare during 1980-1987 and whether welfare was received in 1987 significantly reduce self-esteem measured in 1987 , controlling for self-esteem measured in $1980 .^{5}$

Our literature review points to several ways in which this study advances the analysis of the relationships between attitude and personality characteristics and welfare use. It is the only study to analyze social-psychological determinants of entry into welfare. Because we have complete welfare histories starting at a young age, we can distinguish initial spells of AFDC from higher-order ones and therefore can be confident that we are modeling determinants of initial AFDC use. While earlier studies of exit or the consequences of welfare use each examined three or fewer attitude and personality characteristics, the richness of the NLSY allows us to examine the effects of a broader set of seven such characteristics, controlling for many other personal and family background variables. We use measures collected at relatively early ages, prior to demographic and economic events such as teen pregnancy and birth, finding and losing jobs, divorce, or participation in AFDC or other income-tested programs that may affect those measures. Thus, we are able to distinguish the exogenous effects of these characteristics 
on welfare use from the effects of welfare on those same characteristics. Last, monthly AFDC

participation data in the NLSY allow better estimates of welfare dynamics than is possible in studies that use annual measures of welfare use (Gritz and MaCurdy 1991).

\section{A MODEL OF HOW ATTITUDE AND PERSONALITY CHARACTERISTICS AFFECT WELFARE PARTICIPATION}

Figure 1 presents a structural model of the determinants of welfare participation that explicitly incorporates attitudes and personality characteristics. The model lays out the routes by which such characteristics may affect the process leading to receipt of welfare. We believe Figure 1 captures the main causal linkages analysts (e.g., Mead, 1992) and other observers have in mind when they assert that such characteristics are likely to affect the decision to go on welfare. It also takes into account the likely role of systemic structural factors and family background variables beyond individual control since socioeconomic outcomes plausibly are the product of these factors as well.

A young woman's family background and the opportunity structure and social environment when she is growing up influence the formation of her attitudes and the development of her self-esteem and locus of control as a teenager. We do not advocate any particular theory about how family background affects personality and shapes attitudes; all we claim is that it clearly does. A woman's childhood opportunity structure and social environment are also likely to affect her attitudes, self-esteem, and locus of control. For example, the quality of the schools she attends and her peer groups may affect her attitudes toward school. Similarly, the labor market experiences of older neighborhood women that she observes when a child may affect her attitudes about women's work roles. ${ }^{6}$

For a young woman to receive welfare, she must satisfy two eligibility conditions. Demographic eligibility requires that she have a dependent child and either be a single parent or, in some cases, be married to an unemployed husband. ${ }^{7}$ The financial eligibility rules require that her "countable" private 


\section{Figure 1}

Structural Model of Welfare Participation Incorporating Attitudes and Personality Characteristics

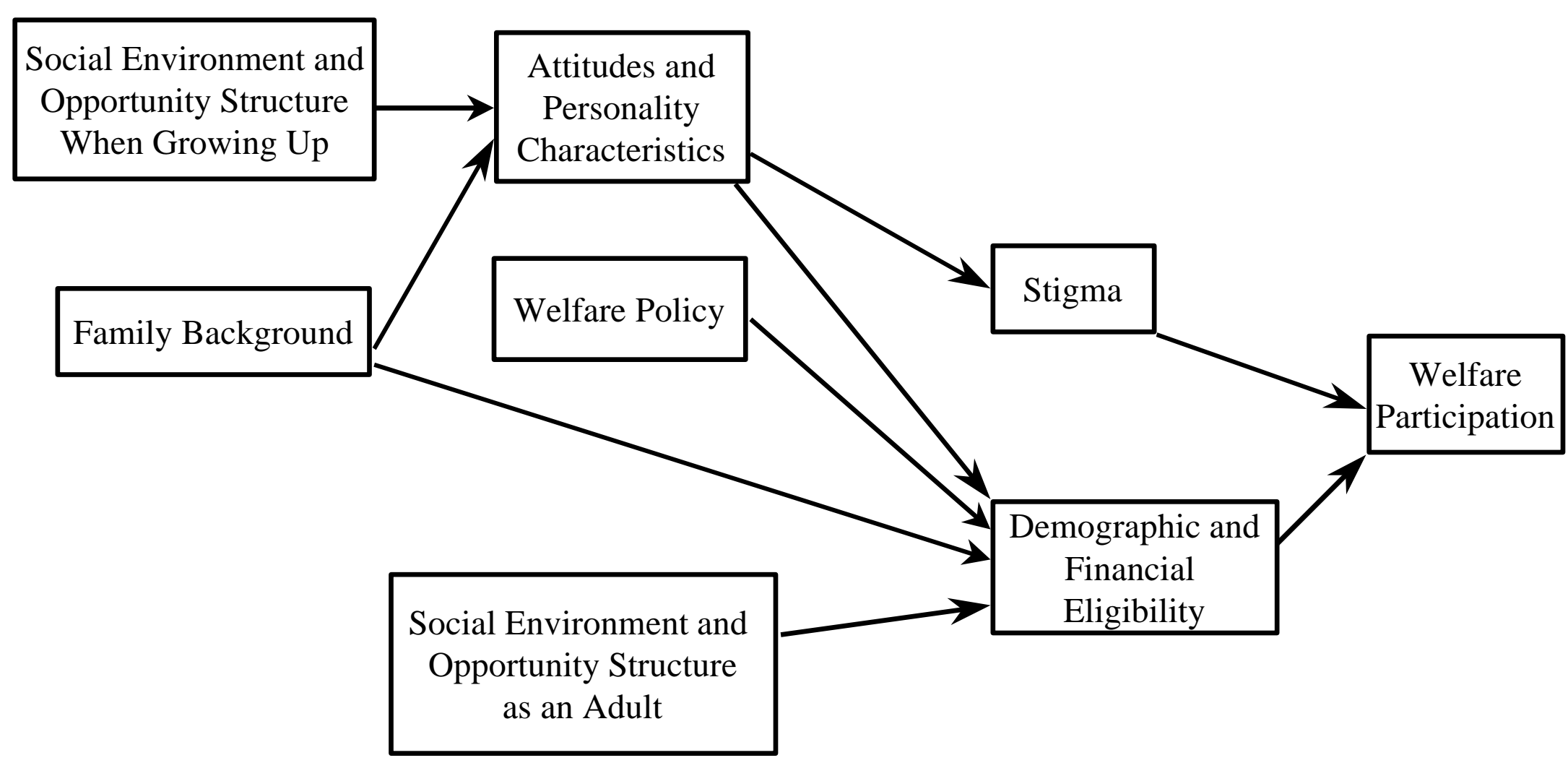


income and assets fall below limits established in her state of residence. The model posits a role for attitudes and other personality characteristics in determining each of these conditions. In addition, family background, state welfare benefit levels, and the social and economic environment a woman faces as an older teen and young adult will influence the likelihood of her being eligible.

Empirical evidence that attitudes and personality characteristics influence the likelihood of demographic eligibility by affecting premarital childbearing, marriage, and divorce comes from several recent studies. Clarkberg, Stolzenberg, and Waite (1995) find that attitudes and values affect the decision to form a union and, if so, the choice between marriage and cohabitation. Esterberg, Moen, and Dempster-McCain's (1994) longitudinal study of white married women finds that higher self-esteem early in the marriage increases the chances of subsequent divorce.

Plotnick's (1992) analysis of premarital childbearing among young white women presents a conceptual framework derived from problem behavior theory (Jessor and Jessor, 1977) and related theories that tie attitudes and personality characteristics to behavior. He finds that the likelihood of premarital pregnancy and the decision to resolve a premarital pregnancy by abortion, marriage, or becoming an unwed mother are partly determined by young women's self-esteem, locus of control, attitudes toward school, educational expectations, and family role attitudes. Moore et al. (1995) review other results showing that attitude and personality variables influence behaviors leading to early and premarital childbearing and, hence, are likely to partly determine welfare eligibility.

Evidence that attitudes and personality characteristics influence a woman's employment, earnings, and financial status is limited. Andrisani (1977) reports a link between greater self-efficacy and earnings among men. Attempts at replication by Duncan and Morgan (1981) fail to substantiate the result for a broader population of men. Parcel and Mueller (1983) find a statistically significant impact of selfefficacy on earnings net of labor market and human capital characteristics among black female householders, but not among white female householders. The general tenor of early research is that 
effects of attitudes and personality characteristics on economic outcomes are modest and generally statistically insignificant (Corcoran et al., 1985).

More recent work reports stronger effects. Using the NLSY, Goldsmith, Veum, and Darity (1997) report that self-esteem and locus of control are positively related to wages. Szekelyi and Tardos (1993) analyze the PSID and find highly significant effects of an expectancy measure of motivation on the level and growth of labor income for both male and female household heads during the 1973-1987 period. Their measure combines items on locus of control, planning for the future, and trust in others. Duncan, Dunifon, and Knutson (1996) also use the PSID to assess the effect of personal efficacy and other noncognitive traits observed in 1972 on men's real hourly wages observed during 1988-1992. Sense of personal efficacy and a preference for challenge versus affiliation at work have consistent, positive relationships to wages. At the same time, many noncognitive traits show no relationship to wages. Duncan et al. (1996) speculate that the stronger effects of more recent analyses of the PSID may appear because the lag between measurement of the social-psychological characteristics and the outcomes is now sufficiently long that the influence of those characteristics has had time to manifest itself more fully.

If a woman meets the formal demographic and financial eligibility conditions, she must then apply for and accept assistance. Attitudes and other personality characteristics may also influence this outcome. It is well known that many persons eligible for welfare do not receive it (Blank and Ruggles, 1996). The likelihood of seeking benefits is affected by objective reasons such as being poorly informed about program rules and the application process, or being eligible for relatively small amounts (Allin and Beebout, 1989). But the likelihood may also be affected by an individual's subjective willingness to bear the stigma of being on welfare.

Welfare "stigma" refers to the negative social-psychological effects of receiving public assistance. It may arise because nonrecipients have negative attitudes toward recipients or resent paying 
taxes to support them, and because recipients feel more negatively about themselves for becoming “dependent” (Rainwater, 1982; Besley and Coate, 1992). Social-psychological characteristics are likely to affect feelings about stigma. Figure 1, therefore, shows a link between attitudes and personality characteristics and welfare participation acting via the effect of stigma.

Several empirical studies have tried to measure the effect of stigma on AFDC participation. Moffitt (1983) finds evidence of stigma related to participating in AFDC, but not to the amount of money received from AFDC. Bassi (1990) uses data from 1967 to 1981 to estimate changes in stigma or other participation barriers over time. She finds significant but small changes, which could result from decreases in stigma or increases in some extra benefits like Medicaid. Moffitt's work suggests that stigma or attitudes could be an important factor in AFDC participation, while Bassi's suggests the significance of stigma may have declined over time. Osterman's (1991) indicator of stigma, though, is not related to welfare participation in a cross-section survey.

Figure 1 does not show direct effects of family background on welfare participation. Rather, the impact of family background is transmitted through its effects on demographic and financial eligibility and on attitudes and personality characteristics, which in turn help determine eligibility and willingness to apply for assistance. Similarly, the effects on welfare use of the social environment, opportunity structure, and social-psychological characteristics are also transmitted indirectly.

The model in Figure 1 may be viewed as a specialized adaptation of more general theories that posit a link from attitudes and personality characteristics to social behavior. Problem behavior theory (Jessor and Jessor, 1977), for example, maintains that behaviors are functions of the individual's personality system and perceived environment. The personality system has three components. In the "personal belief structure," beliefs about self and about self in relation to society affect the willingness to engage in nonconforming or stigmatized behavior such as welfare use. Self-esteem and locus of control are part of the personal belief structure. In the "motivational-instigational structure," the values placed on 
goals and the expectations of attaining those goals influence behavior. This suggests that attitudes about employment and education may be related to behaviors linked to subsequent welfare use. In the "personal control structure," personal characteristics reflect personal moral standards and regulate behavior. Attitudes about women's family and occupational roles, as well as personal views about the acceptability of collecting welfare, fit in this category of influences on welfare use. ${ }^{8}$ A similar framework provided by Eagly and Chaiken (1993) identifies the parallel structures of self-identity outcomes, utilitarian outcomes, and normative outcomes as influences on intended behavior, and subsequently on behavior.

We do not estimate the complete model of Figure 1. Because our focus is on examining whether attitudes and personality characteristics affect welfare participation, we do not estimate the determinants of these variables. In addition, we do not estimate determinants of the full process leading to welfare participation. Rather, we estimate a partial reduced form model that omits explicit modeling of demographic and financial eligibility and of stigma. Figure 2 shows this model. With the elimination of the eligibility and stigma outcomes, the model now indicates a direct link between family background characteristics and welfare participation because such characteristics help determine a young woman's future income and marriage prospects.

A variant on Figure 2 that we also estimate includes academic achievement during high school as a determinant of welfare participation. Academic achievement is a good indicator of earnings capacity (Neal and Johnson, 1996). It is also likely that attitudes and personality characteristics may be affected by academic achievement, so including it may provide better estimates of the effects of these characteristics on welfare participation. While it is likely that attitudes and personality characteristics affect academic achievement, and vice versa, given the focus of this study we do not estimate these relationships. ${ }^{9}$ 


\section{Figure 2}

Reduced Form Model of Welfare Participation Incorporating Attitudes and Personality Characteristics

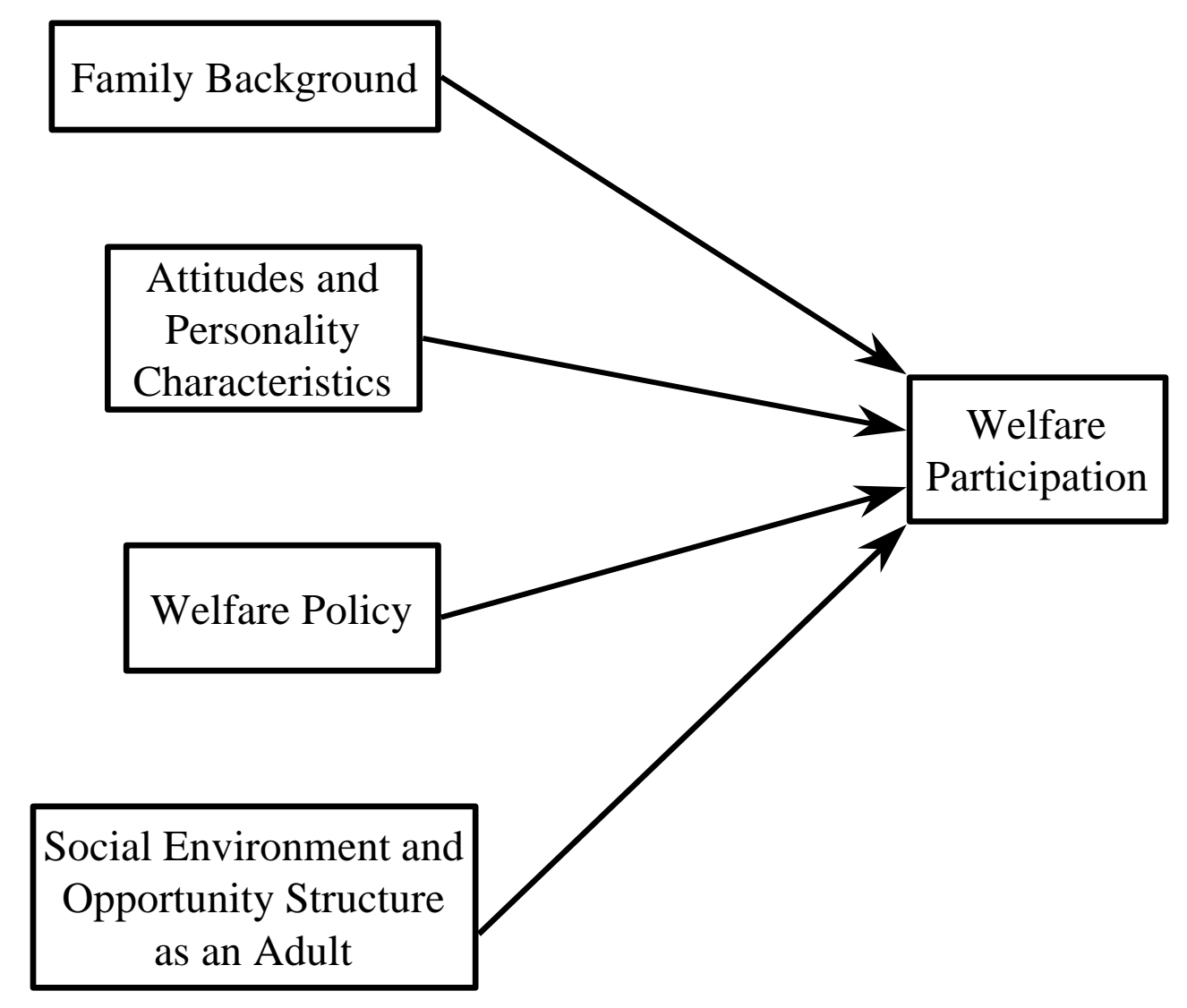




\section{SAMPLE, VARIABLES, AND STATISTICAL METHOD}

The NLSY is a nationally representative sample of young men and women aged 14-21 in 1979. Sample members have been re-interviewed every year since 1979, providing longitudinal data on many aspects of their lives. The NLSY is particularly appropriate for this study because of the large number of young respondents and the availability of data on welfare participation, family background, and measures of self-esteem, locus of control, and attitudes possibly related to welfare use.

Most of the social-psychological characteristics we examine are measured in 1979; one is measured in 1980. Young women in their late teens or early twenties in 1980 may already have experienced a premarital birth or a divorce and received welfare. Characteristics measured in 1979 or 1980 could have been affected by these life experiences. To minimize this source of endogeneity, we limit the sample to women who were 14 to 16 years old in 1979 . The age restriction also allows analysis of time until welfare participation with negligible loss of observations to left censoring because of very early welfare participation. ${ }^{10}$ We use data through the 1992 survey, when our respondents were 27 to 29 years old, and there is information on welfare use for the 14 years from 1978 through 1991. The sample size is 2,153 before cases are dropped because of missing data.

\section{Dependent Variables}

This study investigates two related dependent variables. The first is the likelihood of any AFDC participation between ages 15 and 25. This dependent variable ignores the duration until AFDC participation and simply considers whether any participation occurred during a woman's adolescence and early adult years. Using standard cross-section logit regression, we analyze this outcome among all women in the sample, of whom about 15 percent received AFDC by age 25 . Since having a dependent child is the major demographic requirement for eligibility, we also conduct a similar analysis in which 
we limit the sample to women who have had a child by age 25 . Among such women, 30 percent have participated by age 25 .

The second dependent variable is the timing of initial AFDC participation. We analyze this outcome using Cox proportional hazard partial likelihood models when there are no time-varying covariates, and using discrete logit hazard models when some of the covariates vary over time. In the discrete logit models the spell length is one month, corresponding to the accounting period for AFDC. In either hazard model the coefficients show the effects of explanatory factors on the likelihood of leaving the state of not being on welfare, conditional on not having yet participated. ${ }^{11}$ A positive coefficient means that an increase in the explanatory variable is associated with a faster transition onto welfare.

We again consider two versions of this dependent variable. The first is the number of months between the month a respondent turned 15 and either the first month of AFDC participation or, for nonparticipants, the end of continuous data collection. Hazard analysis of this outcome shows the effects of explanatory variables on the likelihood of going on welfare conditional on no previous participation. Since receipt of AFDC depends on being in the later stages of pregnancy or having a child, time until first participation on AFDC can be divided into time until demographic eligibility, and, conditional on such eligibility, time until participation. Thus, for the second version we restrict the sample to women who have a child prior to 1992 and examine time until AFDC participation starting from 4 months prior to the birth of a child, when a woman can enroll in AFDC if she is otherwise eligible. ${ }^{12}$

Some women under age 18 who are still part of an adult's household do not report receipt of AFDC because payments are received by an older adult for the entire household. If such women report receiving AFDC once they leave their parent's household, which is likely, early underreporting would have little effect on the logit estimates. Underreporting of early AFDC participation may, however, affect the results of the hazard models. ${ }^{13}$ 
Attitude and Personality Variables

We obtain measures of five attitudes and two personality characteristics from the NLSY. ${ }^{14}$ All were measured in 1979 with the exception of the self-esteem index, which was measured in 1980 . We briefly describe each one here and discuss whether theory and the empirical evidence reviewed above predict the likely direction of each variable's impact, or yield an ambiguous prediction. (Specific items and other details for all seven variables appear in the Appendix.)

The ten-item Rosenberg self-esteem scale gauges respondents' sense of self-worth. Higher values indicate higher self-esteem. Going on welfare occurs to a minority of women, carries social disapproval, and thereby qualifies as deviant and stigmatizing behavior. Self-esteem theory (Kaplan, 1975; Rosenberg, 1990) concludes that persons with low self-esteem are more likely to engage in such behaviors. This reasoning and the empirical evidence linking higher self-esteem to lower eligibility for welfare imply a negative relationship between measured self-esteem and both the probability of ever going on welfare and the rate of leaving the state of not being on welfare. However, if higher self-esteem raises the likelihood of divorce, there is a reason for a positive relationship between self-esteem and welfare use.

The Rotter scale for locus of control (self-efficacy) captures the extent to which respondents believe they can control their lives through self-motivation and self-determination (internal control) as opposed to believing that luck or fate controls their lives (external control). The NLSY contains a fouritem subset from this scale. Higher scores indicate a more internal locus of control. The associations between a more internal locus of control and both higher earnings and a lower likelihood of premarital pregnancy imply a negative relationship between a more internal locus of control and our measures of welfare participation.

Locus of control may also affect welfare use via its impact on feelings of stigma. If a more internal locus of control is related to the belief that one can and should be self-sufficient and not receive 
welfare, one again would expect a negative relationship between welfare participation and a more internal locus of control.

Alternatively, if welfare is seen as a tool for becoming independent from a former spouse or family members, or providing for one's family, it might be more acceptable to women with higher selfesteem and a more internal locus of control. The possibility of this last relationship (though a priori, we think it is unlikely to hold for many women) means there are not unambiguous predictions about the directions of effect of both self-esteem and locus of control.

A ten-item index of attitudes toward school assesses how satisfied a respondent feels about her schooling experience to date. It may reflect the sense of achievement in school and commitment to educational goals. Some young women did not answer the school attitude questions. Many of these nonrespondents were not in school during the survey in 1979. We include an indicator for missing school attitudes in the models. Better attitudes toward school are associated with a lower likelihood of premarital pregnancy and are likely to promote higher educational attainment and, hence, earnings. One would thus expect school attitudes to be negatively related to the measures of welfare participation.

Two indicators of personal attitudes likely to affect welfare participation are indexes that gauge aversion to accepting welfare and commitment to work. The aversion to welfare index is the sum of responses to two items asking about willingness to accept food stamps or cash public assistance under straitened circumstances. Higher values indicate more aversion to using welfare. Work commitment is measured by a seven-item index of willingness to work at various fairly menial jobs for $\$ 2.50$ an hour in 1979 (\$5.40 in 1996 dollars). ${ }^{15}$ Higher values indicate greater willingness to take the jobs. One would expect respondents with higher aversion to welfare and greater work commitment to be less likely to go on AFDC. ${ }^{16}$

Alternatively, the work commitment index may be an indicator of a respondent's expectations about the market wage she can realistically expect. Under this interpretation, young women who expect 
to earn relatively low wages are more willing to accept a low-wage job and have high index values. If their expectations are reasonably accurate, their opportunity cost of going on welfare is low, and they would be more likely to go on welfare. Conversely, persons with lower index values-those with higher expected wages—-would be less likely to go on welfare. Thus, the social-psychological and economic interpretations of this index imply different signs on its coefficient.

Two variables measure attitudes toward women's employment. One is an index of the respondent's attitudes toward work and family roles for married women formed from items dealing with the conflict between work outside the home and fulfillment of women's traditional family roles. The other is an index of her assessment of an influential person's reactions to nontraditional employment and family roles. Higher values on both indicate more support for nontraditional roles. To the degree that higher values on these two variables reflect more positive attitudes toward paid work and nontraditional work roles for women and less commitment to staying home to care for children, they would tend to reduce the likelihood of AFDC use. Alternatively, women with these characteristics and, perhaps, other more feminist attitudes may be less willing to depend on a husband or partner for economic support and may more readily seek public support when in need.

\section{Control Variables}

Family background and exogenous personal characteristics may help determine the likelihood of welfare participation by affecting the economic resources available to a young woman, her future income prospects, or her preferences about work, education, marriage, childbearing, or welfare use in ways that are not captured by the available attitude and personality variables. We include an extensive set of such characteristics. An indicator of educational materials in the house for the year the respondent was 14 years old is the sum of dummy variables for whether the family had magazine or newspaper subscriptions or possessed a library card. ${ }^{17}$ Another proxy for the childhood educational environment is the highest grade completed by the respondent's mother; we also include a dummy indicating whether the 
respondent knew that grade. A dummy variable for foreign language use within the family may reflect differences in cultural assimilation. Family structure during the respondent's childhood is reflected in variables measuring the number of years between birth and age 15 spent living with both natural parents, mother only, or mother and stepfather. The reference category is years living with any other set of adults (not with mother). The number of siblings of the respondent further characterizes family structure. A dummy variable for whether the female adult in the household was employed in the year the respondent was 14 years old may indicate differences in economic role models or adult supervision. Dummy variables for family poverty status and urban and southern residence when the respondent was age 14 are other indicators of the social and economic environment. ${ }^{18}$

Religion and religiosity may affect welfare participation by influencing personal attitudes or by affecting the material resources available through a religious community. The model includes dummy variables for upbringing as Baptist, non-Baptist Protestant, Catholic, or "Jewish or other." "No religious affiliation" is the reference category. Frequency of attendance at religious services in 1979 is categorized as often ( 1 or more times per week), occasional (1-3 times per month), or rare (less than once a month), with never as the reference category.

The key personal characteristic, race, is indicated with dummies for black, Asian/Pacific Islander, American Indian, and Hispanic (with white as the reference category). In models that include academic achievement, the respondent's score on the Armed Forces Qualifying Test (AFQT) serves as the indicator of achievement (as well as ability and earnings capacity). In analyses restricted to mothers, we include her age when her child was born. Younger first-time mothers may be more likely to go on welfare because of fewer employment opportunities or economic assets.

The economic benefits of each state's welfare program are measured by the sum of the real AFDC, food stamp, and Medicaid benefits available to a family residing in the state and having no other sources of income-the welfare "guarantee." Economic theory implies that a higher guarantee would 
increase the chance of ever using welfare and the rate of entry. For the cross-section logit models, the benefit level is set at its value either when the respondent was 15 or when she became a mother. In the discrete hazard models, it is set at its value during the first month of the observation period (i.e., age 15 or 4 months before birth), then varied in accord with changes in state policy. ${ }^{19}$

To control for local social and economic conditions, the discrete logit hazard models include dummy variables for state- and year-specific effects. Adding state dummies controls for unobservable state-level differences in welfare norms and administration and the overall social and economic climate. Year dummies help control for secular trends or cyclical patterns in welfare participation, and for the aging of the sample.

Table 1 provides means and standard deviations of the explanatory factors for the entire sample and separately for women who receive AFDC before age 25 and those who do not. Means for many variables differ significantly between recipients and nonrecipients. Compared with nonrecipients, recipients show lower self-esteem, poorer attitudes about school, more traditional attitudes toward women's employment, and lower aversion to going on welfare but, surprisingly, greater work commitment. Women who were never on AFDC by age 25 have more educational resources at home, have better-educated mothers and fewer siblings, and have spent more time with both parents and less with a single mother or a stepfather. Their families are much less likely to have been poor. Among nonrecipients the proportion of Catholics and frequency of religious attendance is higher, the proportion of Baptists lower. Women never on AFDC are less likely to be black and have higher AFQT test scores. These comparisons of means foreshadow a number of results of the multivariate analyses.

\section{FINDINGS}

We explore the relationship between initial AFDC participation and attitudes and personality characteristics by starting with descriptive life tables and simple bivariate logit and hazard models. We 
TABLE 1

Descriptive Statistics for Entire Sample and by AFDC Participation

\begin{tabular}{|c|c|c|c|c|c|c|}
\hline & \multirow{2}{*}{\multicolumn{2}{|c|}{ Entire Sample }} & \multicolumn{4}{|c|}{ AFDC Status at Age 25} \\
\hline & & & \multicolumn{2}{|c|}{ Never on AFDC } & \multicolumn{2}{|c|}{ Ever on AFDC } \\
\hline & Mean & Std. Dev. & Mean & Std. Dev. & Mean & Std. Dev. \\
\hline \multicolumn{7}{|l|}{ Psychosocial Characteristics: } \\
\hline Locus of control & 9.19 & 2.37 & 9.15 & 2.41 & 9.44 & 2.22 \\
\hline Self-esteem & 31.44 & 4.06 & $31.56^{*}$ & 4.06 & 30.77 & 4.06 \\
\hline School attitudes & 31.81 & 3.91 & $31.99 *$ & 3.78 & 31.00 & 4.32 \\
\hline Missing school attitude & 0.05 & 0.23 & $0.03^{*}$ & 0.18 & 0.15 & 0.36 \\
\hline Work commitment & 2.87 & 2.03 & $2.82 *$ & 2.01 & 3.25 & 2.06 \\
\hline Aversion to using welfare & 3.33 & 0.81 & $3.33 *$ & 0.80 & 3.20 & 0.85 \\
\hline Influential gender roles & 16.38 & 3.05 & 16.48 & 3.03 & 16.14 & 2.94 \\
\hline Gender/work attitudes & 17.83 & 3.07 & $17.98 *$ & 3.02 & 17.18 & 3.10 \\
\hline Missing influential roles & 0.07 & 0.26 & 0.07 & 0.25 & 0.11 & 0.31 \\
\hline \multicolumn{7}{|l|}{ Family Background: } \\
\hline Educational materials at home & 2.24 & 0.90 & $2.33 *$ & 0.85 & 1.82 & 1.00 \\
\hline Mother's grade & 11.50 & 2.62 & $11.77 *$ & 2.60 & 10.54 & 2.37 \\
\hline Knows mother's grade & 0.96 & 0.20 & 0.96 & 0.19 & 0.94 & 0.24 \\
\hline Foreign language & 0.12 & 0.33 & 0.12 & 0.32 & 0.09 & 0.29 \\
\hline Years with both parents & 12.12 & 5.03 & $12.70 *$ & 4.55 & 9.50 & 6.01 \\
\hline Years with mother only & 1.33 & 3.31 & $1.07 *$ & 2.94 & 2.60 & 4.52 \\
\hline Years with mother and stepfather & 0.74 & 2.47 & $0.58 *$ & 2.19 & 1.49 & 3.28 \\
\hline Number of siblings & 3.25 & 2.25 & $3.06^{*}$ & 2.09 & 4.25 & 2.73 \\
\hline Poor at age 14 & 0.15 & 0.36 & $0.11 *$ & 0.31 & 0.35 & 0.48 \\
\hline \multicolumn{7}{|l|}{ Mother worked when respondent } \\
\hline was age 14 & 0.60 & 0.49 & $0.62 *$ & 0.49 & 0.55 & 0.50 \\
\hline Urban resident, age 14 & 0.77 & 0.42 & 0.77 & 0.42 & 0.76 & 0.43 \\
\hline Southern resident, age 14 & 0.34 & 0.47 & 0.34 & 0.48 & 0.31 & 0.46 \\
\hline \multicolumn{7}{|l|}{ Religious Variables: } \\
\hline Baptist & 0.26 & 0.44 & $0.23 *$ & 0.42 & 0.38 & 0.49 \\
\hline Protestant & 0.27 & 0.44 & 0.28 & 0.45 & 0.24 & 0.43 \\
\hline Catholic & 0.32 & 0.46 & $0.34 *$ & 0.47 & 0.19 & 0.39 \\
\hline Jewish or other & 0.11 & 0.32 & 0.11 & 0.31 & 0.14 & 0.34 \\
\hline Rarely attend & 0.22 & 0.41 & 0.21 & 0.40 & 0.22 & 0.42 \\
\hline Occasionally attend & 0.19 & 0.39 & 0.18 & 0.39 & 0.22 & 0.41 \\
\hline Often attend & 0.46 & 0.50 & $0.48 *$ & 0.50 & 0.40 & 0.49 \\
\hline
\end{tabular}


TABLE 1, continued

\begin{tabular}{|c|c|c|c|c|c|c|}
\hline & \multirow{2}{*}{\multicolumn{2}{|c|}{ Entire Sample }} & \multicolumn{4}{|c|}{ AFDC Status at Age 25} \\
\hline & & & \multicolumn{2}{|c|}{ Never on AFDC } & \multicolumn{2}{|c|}{ Ever on AFDC } \\
\hline & Mean & Std. Dev. & Mean & Std. Dev. & Mean & Std. Dev. \\
\hline \multicolumn{7}{|l|}{ Race/Ethnicity: } \\
\hline Black & 0.14 & 0.35 & $0.10^{*}$ & 0.30 & 0.36 & 0.48 \\
\hline Asian/Pacific Islander & 0.01 & 0.11 & 0.01 & 0.12 & 0.01 & 0.03 \\
\hline American Indian & 0.04 & 0.19 & 0.04 & 0.19 & 0.04 & 0.20 \\
\hline Hispanic & 0.06 & 0.23 & 0.05 & 0.22 & 0.07 & 0.26 \\
\hline \multicolumn{7}{|l|}{ Other Characteristics: } \\
\hline AFQT score & 68.31 & 18.48 & $71.4^{*}$ & 17.0 & 54.5 & 19.0 \\
\hline Age at birth (mothers only) & & & $22.34 *$ & 2.89 & 18.72 & 2.13 \\
\hline \multicolumn{7}{|l|}{ Welfare Policy: } \\
\hline $\begin{array}{l}\text { AFDC, food stamp, and } \\
\text { Medicaid benefit per } \\
\text { month, } 1980\end{array}$ & 597 & 125 & 595 & 125 & 602 & 130 \\
\hline Unweighted N & 1573 & & 1113 & & 352 & \\
\hline
\end{tabular}

Notes: Data are weighted to reflect survey sampling. Combined sample size for AFDC samples is smaller than for entire sample because not all respondents have data for all years prior to age 25 . Reference categories are years lived apart from mother, white, no religion, never attend services.

* indicates difference in means significant at 5 percent level. 
then elaborate the empirical models until we obtain estimates for the model of Figure 2. The multivariate results appear in a series of three tables. Table 5 has estimates for a model that includes all the attitude and personality variables but no other explanatory variables. In contrast to the bivariate results, these suggest which social-psychological characteristics affect welfare use, controlling for the often significant correlation among these variables (see Appendix Table 1). The model in Table 6 adds family background characteristics, which are hypothesized to directly affect welfare use, and, hence, assesses the extent to which the significant relationships observed in Table 5 are spurious. The model in Table 7 includes welfare benefits and state and year effects to provide estimates of the full model in Figure 2. For simplicity, only coefficients on the attitudes and personality characteristics are shown. (Full results are available from the authors upon request.)

\section{$\underline{\text { Life Tables }}$}

Table 2 presents a life table for AFDC participation in each year following age 15 for all women. Before age 18, about 98 percent of women had not been on AFDC. Between 18 and 21, almost 10 percent go on AFDC, so that 89 percent have never been on before age 22. After age 24 , few women who have not already received AFDC enter the program for the first time. The hazard rate is very low and the survival rate flattens out again. About 85 percent of women have not been on AFDC by age 25. First-time AFDC participation is most likely for women between 18 and 24.

To analyze the time between demographic eligibility for AFDC (fifth month of pregnancy) and AFDC participation, we limit the sample to mothers. Table 3 shows the life table for the time until mothers go on AFDC. The largest group of participants starts AFDC in the first year of their baby's life. About 18 percent of mothers participate in AFDC in the first year. In the first 3 years after eligibility, 30 percent have participated. The cumulative participation rate increases more slowly in later years, so that by 10 years following the baby's birth 40 percent have been on AFDC. The high initial rates of 


\section{TABLE 2}

Life Table of Time until AFDC Participation after Age 15

\begin{tabular}{|c|c|c|c|c|}
\hline Start of Interval (Age) & $\begin{array}{c}\text { Proportion } \\
\text { Terminating }\end{array}$ & $\begin{array}{c}\text { Proportion } \\
\text { Surviving } \\
\end{array}$ & $\begin{array}{c}\text { Monthly } \\
\text { Hazard Rate }\end{array}$ & $\begin{array}{c}\text { Cumulative } \\
\text { Survival }\end{array}$ \\
\hline 15 & 0.002 & 0.998 & 0.000 & 1.00 \\
\hline 16 & 0.008 & 0.992 & 0.001 & 0.99 \\
\hline 17 & 0.013 & 0.987 & 0.001 & 0.98 \\
\hline 18 & 0.030 & 0.971 & 0.003 & 0.95 \\
\hline 19 & 0.022 & 0.978 & 0.002 & 0.93 \\
\hline 20 & 0.021 & 0.979 & 0.002 & 0.91 \\
\hline 21 & 0.019 & 0.981 & 0.002 & 0.89 \\
\hline 22 & 0.022 & 0.978 & 0.002 & 0.87 \\
\hline 23 & 0.020 & 0.980 & 0.002 & 0.85 \\
\hline 24 & 0.010 & 0.990 & 0.001 & 0.85 \\
\hline 25 & 0.009 & 0.991 & 0.001 & 0.84 \\
\hline 26 & 0.012 & 0.989 & 0.001 & $\mathbf{0 . 8 3}$ \\
\hline 27 & 0.008 & 0.992 & 0.001 & 0.82 \\
\hline 28 & 0.007 & 0.993 & 0.001 & 0.82 \\
\hline
\end{tabular}

Notes: Data are weighted to reflect sampling. N=2087. 


\section{TABLE 3}

Life Table of Time until AFDC Participation after Fifth Month of Pregnancy

\begin{tabular}{ccccc}
\hline & $\begin{array}{c}\text { Proportion } \\
\text { Start of Interval (Years) }\end{array}$ & $\begin{array}{c}\text { Proportion } \\
\text { Terminating }\end{array}$ & $\begin{array}{c}\text { Monthly } \\
\text { Sazard Rate }\end{array}$ & $\begin{array}{c}\text { Cumulative } \\
\text { Survival }\end{array}$ \\
\hline $\mathbf{0}$ & & & & \\
$\mathbf{1}$ & 0.181 & 0.820 & 0.017 & $\mathbf{0 . 8 2}$ \\
$\mathbf{2}$ & 0.063 & 0.937 & 0.005 & $\mathbf{0 . 7 7}$ \\
$\mathbf{3}$ & 0.042 & 0.958 & 0.004 & $\mathbf{0 . 7 4}$ \\
$\mathbf{4}$ & 0.052 & 0.948 & 0.004 & $\mathbf{0 . 7 0}$ \\
$\mathbf{5}$ & 0.029 & 0.971 & 0.003 & $\mathbf{0 . 6 8}$ \\
$\mathbf{6}$ & 0.039 & 0.961 & 0.003 & $\mathbf{0 . 6 5}$ \\
$\mathbf{7}$ & 0.007 & 0.993 & 0.001 & $\mathbf{0 . 6 5}$ \\
$\mathbf{8}$ & 0.034 & 0.966 & 0.003 & $\mathbf{0 . 6 2}$ \\
$\mathbf{9}$ & 0.009 & 0.991 & 0.001 & $\mathbf{0 . 6 2}$ \\
$\mathbf{1 0}$ & 0.030 & 0.970 & 0.003 & $\mathbf{0 . 6 0}$ \\
$\mathbf{1 1}$ & 0.026 & 0.975 & 0.002 & $\mathbf{0 . 5 9}$ \\
$\mathbf{1 2}$ & 0.067 & 0.933 & 0.006 & $\mathbf{0 . 5 5}$ \\
\hline
\end{tabular}

Notes: Data are weighted to reflect sampling. Sample is limited to women with children. N=1208. 
participation most likely reflect higher participation for younger first-time mothers and the greater burden of caring for very young children.

\section{Bivariate Relationships}

Table 4 summarizes results of descriptive bivariate logit and Cox hazard models. In this and succeeding tables the sample for the "Since Age 15" logit estimates includes all women with complete data for the study period. The sample for the "Since First Pregnancy" logit estimates is further limited to women who gave birth before age 25. The "Since Age 15" hazard models estimate determinants of the number of months between age 15 and a woman's first month on AFDC. The "Since First Pregnancy" hazard models are limited to women who had children and show determinants of the time between the fifth month of pregnancy and the first month on AFDC.

Table 4 shows strong associations between welfare use and six of the seven attitude and personality variables. Five are significant in at least three of the four models, always in the same direction. Work/gender role attitudes have a significant negative association in the two "Since Age 15" models. The measure of an influential person's views about nontraditional work is never significant. Consistent with expectation, a more favorable attitude toward school and greater aversion to using welfare are associated with a lower likelihood of going on AFDC. Since theory does not offer clear-cut predictions for the direction of effect of self-esteem, locus of control, the work commitment/expected wage index, and work/gender role attitudes, the significant associations simply suggest these characteristics may affect behavior.

\section{$\underline{\text { Multivariate Models }}$}

When the seven attitude and personality variables are jointly included (Table 5), the coefficients on school attitudes, indices of work commitment and aversion to using welfare, and attitudes about work and family roles show the same pattern of significance and have roughly the same magnitudes as in 


\section{TABLE 4}

\section{Relationship between Welfare Use and Attitudes and Personality Characteristics: Bivariate Estimates ${ }^{\mathrm{a}}$}

(Standard Errors in Parentheses)

\begin{tabular}{|c|c|c|c|c|}
\hline & \multicolumn{2}{|c|}{ Since Age 15 Model } & \multicolumn{2}{|c|}{$\underline{\text { Since First Pregnancy Model }}$} \\
\hline & Logit & Cox Hazard & Logit & Cox Hazard \\
\hline Self-esteem & $\begin{array}{l}-.051 * * \\
(.041)\end{array}$ & $\begin{array}{l}-.060 * * \\
(.012)\end{array}$ & $\begin{array}{l}-.028 \\
(.017)\end{array}$ & $\begin{array}{l}-.031 * \\
(.013)\end{array}$ \\
\hline Locus of control & $\begin{array}{l}.053^{*} \\
(.023)\end{array}$ & $\begin{array}{l}.067 * * \\
(.019)\end{array}$ & $\begin{array}{c}.029 \\
(.029)\end{array}$ & $\begin{array}{l}.041^{*} \\
(.021)\end{array}$ \\
\hline School attitudes & $\begin{array}{l}-.061 * * \\
(.015)\end{array}$ & $\begin{array}{l}-.056^{* *} \\
(.012)\end{array}$ & $\begin{array}{l}-.050 * * \\
(.018)\end{array}$ & $\begin{array}{l}-.043^{* *} \\
(.013)\end{array}$ \\
\hline Work commitment & $\begin{array}{l}.109 * * \\
(.027)\end{array}$ & $\begin{array}{l}.097 * * \\
(.022)\end{array}$ & $\begin{array}{l}.085^{* *} \\
(.031)\end{array}$ & $\begin{array}{l}.064 * * \\
(.023)\end{array}$ \\
\hline Aversion to using welfare & $\begin{array}{l}-.283 * * \\
(.067)\end{array}$ & $\begin{array}{l}-.283^{* *} \\
(.054)\end{array}$ & $\begin{array}{l}-.251 * * \\
(.079)\end{array}$ & $\begin{array}{l}-.233^{* *} \\
(.057)\end{array}$ \\
\hline Work/gender role attitudes & $\begin{array}{l}-.083^{* *} \\
(.018)\end{array}$ & $\begin{array}{l}-.079 * * \\
(.015)\end{array}$ & $\begin{array}{l}-.033 \\
(.021)\end{array}$ & $\begin{array}{l}-.026 \\
(.016)\end{array}$ \\
\hline Influential person's views & $\begin{array}{l}-.017 \\
(.019) \\
\end{array}$ & $\begin{array}{l}-.013 \\
(.015)\end{array}$ & $\begin{array}{c}.004 \\
(.022) \\
\end{array}$ & $\begin{array}{l}.008 \\
(.016) \\
\end{array}$ \\
\hline
\end{tabular}

${ }^{a}$ Each coefficient is from a model that includes only the indicated explanatory variable (and missing value dummy where appropriate) and, in the logit models, a constant.

$*$ = significant at 5 percent level.

$* *$ = significant at 1 percent level. 


\section{TABLE 5}

\section{Relationship between Welfare Use and Attitudes and Personality Characteristics: No Controls for Family Background, Welfare, or Local Conditions ${ }^{\mathrm{a}}$}

(Standard Errors in Parentheses)

\begin{tabular}{|c|c|c|c|c|}
\hline & \multicolumn{2}{|c|}{ Since Age 15 Model } & \multicolumn{2}{|c|}{ Since First Pregnancy Model } \\
\hline & Logit & Cox Hazard & Logit & Cox Hazard \\
\hline Self-esteem & $\begin{array}{l}-.006 \\
(.016)\end{array}$ & $\begin{array}{l}-.019 \\
(.013)\end{array}$ & $\begin{array}{c}.003 \\
(.019)\end{array}$ & $\begin{array}{l}-.006 \\
(.014)\end{array}$ \\
\hline Locus of control & $\begin{array}{c}.014 \\
(.026)\end{array}$ & $\begin{array}{c}.032 \\
(.021)\end{array}$ & $\begin{array}{l}-.005 \\
(.031)\end{array}$ & $\begin{array}{c}.018 \\
(.023)\end{array}$ \\
\hline School attitudes & $\begin{array}{l}-.059 * * \\
(.016)\end{array}$ & $\begin{array}{l}-.052 * * \\
(.013)\end{array}$ & $\begin{array}{l}-.044 * \\
(.019)\end{array}$ & $\begin{array}{l}-.034 * \\
(.013)\end{array}$ \\
\hline Work commitment & $\begin{array}{l}.125 * * \\
(.030)\end{array}$ & $\begin{array}{l}.094 * * \\
(.024)\end{array}$ & $\begin{array}{l}.099 * * \\
(.034)\end{array}$ & $\begin{array}{c}.055^{*} \\
(.024)\end{array}$ \\
\hline Aversion to using welfare & $\begin{array}{l}-.199 * * \\
(.071)\end{array}$ & $\begin{array}{l}-.217 * * \\
(.056)\end{array}$ & $\begin{array}{l}-.205^{*} \\
(.083)\end{array}$ & $\begin{array}{l}-.191 * * \\
(.060)\end{array}$ \\
\hline Work/gender role attitudes & $\begin{array}{l}-.062 * * \\
(.020)\end{array}$ & $\begin{array}{l}-.056 * * \\
(.016)\end{array}$ & $\begin{array}{l}-.018 \\
(.024)\end{array}$ & $\begin{array}{l}-.007 \\
(.017)\end{array}$ \\
\hline Influential person's views & $\begin{array}{l}.006 \\
(.020)\end{array}$ & $\begin{array}{l}.010 \\
(.016)\end{array}$ & $\begin{array}{c}.017 \\
(.024)\end{array}$ & $\begin{array}{c}.019 \\
(.017)\end{array}$ \\
\hline Chi-square $(\mathrm{df}=9)$ & $107 * *$ & $144 * *$ & $44 * *$ & $44 * *$ \\
\hline
\end{tabular}

${ }^{a}$ Each column of coefficients is from a model that includes all the indicated explanatory variables, missing value dummies for school attitudes and influential person's views, and, in the logit models, a constant.

$*$ = significant at 5 percent level.

$* *$ significant at 1 percent level. 
Table 4. However, self-esteem and locus of control no longer show an association with welfare use in either the logit or hazard models. As before, the influential person's views are insignificant.

Table 6 shows that most effects of attitudes and personality characteristics disappear when family background is allowed to directly affect welfare use. Only school attitudes and work commitment consistently remain significant. More positive school attitudes are now associated with a lower likelihood of welfare use only in the two "Since Age 15" models. Conditional on being a mother, school attitudes are not related to welfare use. Note, though, that the dummy for missing school attitude data, an indication of connection to school, is significant in all models. The positive coefficient implies that young women who were not going to school early in the survey, who are almost surely school dropouts given the age range of the sample in 1979, are more apt to go on AFDC. As in the earlier tables, higher values on the work commitment index show a positive relationship with welfare use, which suggests that the index may be a better indicator of the expected wage than of an internalized commitment to work. Self-esteem has a significant negative relationship with welfare use only in the "Since Age 15" hazard model.

Table 7 presents results from the full model of Figure 2. Since this model includes the timevarying welfare guarantee and year dummies, the hazard functions are estimated using discrete logit. The findings are the same as in Table 6 with two exceptions. Now, school attitudes are significant in three of the four models and marginally significant $(\mathrm{p}=.058)$ in the remaining one. In addition, aversion to using welfare is significant in one model with the anticipated negative sign.

Taken together, Tables 4-7 demonstrate that although there are strong associations between welfare use and several attitudes and personality characteristics, most of the associations are not robust to the inclusion of family background characteristics. One can conclude from this evidence that self-esteem, locus of control, personal views about the acceptability of using welfare, and personal and an influential other's attitudes about women's work and family roles affect neither the likelihood of welfare use (at 


\section{TABLE 6}

Relationship between Welfare Use and Attitudes and Personality Characteristics: Controls Only for Family Background ${ }^{a}$

(Standard Errors in Parentheses)

\begin{tabular}{|c|c|c|c|c|}
\hline & \multicolumn{2}{|c|}{ Since Age 15 Model } & \multicolumn{2}{|c|}{$\underline{\text { Since First Pregnancy Model }}$} \\
\hline & Logit & Cox Hazard & Logit & Cox Hazard \\
\hline Self-esteem & $\begin{array}{l}-.019 \\
(.019)\end{array}$ & $\begin{array}{l}-.029 * \\
(.014)\end{array}$ & $\begin{array}{l}-.018 \\
(.022)\end{array}$ & $\begin{array}{l}-.021 \\
(.015)\end{array}$ \\
\hline Locus of control & $\begin{array}{l}-.008 \\
(.031)\end{array}$ & $\begin{array}{c}.015 \\
(.023)\end{array}$ & $\begin{array}{l}-.022 \\
(.037)\end{array}$ & $\begin{array}{c}.019 \\
(.025)\end{array}$ \\
\hline School attitudes & $\begin{array}{l}-.046^{*} \\
(.019)\end{array}$ & $\begin{array}{l}-.037 * * \\
(.014)\end{array}$ & $\begin{array}{l}-.029 \\
(.022)\end{array}$ & $\begin{array}{l}-.024 \\
(.015)\end{array}$ \\
\hline Missing school attitudes & $\begin{array}{l}1.356^{* * *} \\
(.244)\end{array}$ & $\begin{array}{l}.873 * * \\
(.158)\end{array}$ & $\begin{array}{l}1.079 * * \\
(.271)\end{array}$ & $\begin{array}{l}.442 * * \\
(.161)\end{array}$ \\
\hline Work commitment & $\begin{array}{l}.114 * * \\
(.035)\end{array}$ & $\begin{array}{l}.068 * * \\
(.025)\end{array}$ & $\begin{array}{c}.095^{*} \\
(.040)\end{array}$ & $\begin{array}{c}.035 \\
(.027)\end{array}$ \\
\hline Aversion to using welfare & $\begin{array}{c}.007 \\
(.085)\end{array}$ & $\begin{array}{l}-.048 \\
(.063)\end{array}$ & $\begin{array}{l}-.017 \\
(.100)\end{array}$ & $\begin{array}{l}-.062 \\
(.066)\end{array}$ \\
\hline Work/gender role attitudes & $\begin{array}{l}-.033 \\
(.024)\end{array}$ & $\begin{array}{l}-.023 \\
(.018)\end{array}$ & $\begin{array}{c}.002 \\
(.028)\end{array}$ & $\begin{array}{c}.011 \\
(.019)\end{array}$ \\
\hline Influential person's views & $\begin{array}{l}-.028 \\
(.024)\end{array}$ & $\begin{array}{l}-.006 \\
(.018)\end{array}$ & $\begin{array}{l}-.026 \\
(.028)\end{array}$ & $\begin{array}{c}.003 \\
(.018)\end{array}$ \\
\hline Missing views & $\begin{array}{l}-.018 \\
(.243)\end{array}$ & $\begin{array}{l}-.016 \\
(.171)\end{array}$ & $\begin{array}{l}-.401 \\
(.290)\end{array}$ & $\begin{array}{l}-.330^{*} \\
(.191)\end{array}$ \\
\hline Chi-square $(\mathrm{df}=32)$ & $317 * *$ & $366 * *$ & $182 * *$ & $183 * *$ \\
\hline
\end{tabular}

${ }^{a}$ Each column of coefficients is from a model that includes the indicated explanatory variables and missing value dummies, family background characteristics, and, in the logit models, a constant.

$*$ significant at 5 percent level.

$* *=$ significant at 1 percent level. 
TABLE 7

Relationship between Welfare Use and Attitudes and Personality Characteristics: Full Model ${ }^{\mathrm{a}}$

(Standard Errors in Parentheses)

\begin{tabular}{|c|c|c|c|c|}
\hline & \multicolumn{2}{|c|}{ Since Age 15 Model } & \multicolumn{2}{|c|}{ Since First Pregnancy Model } \\
\hline & Logit & Discrete Hazard & Logit & Discrete Hazard \\
\hline Self-esteem & $\begin{array}{l}-.019 \\
(.019)\end{array}$ & $\begin{array}{l}-.033^{*} \\
(.015)\end{array}$ & $\begin{array}{c}.028 \\
(.029)\end{array}$ & $\begin{array}{l}-.014 \\
(.019)\end{array}$ \\
\hline Locus of control & $\begin{array}{l}-.005 \\
(.031)\end{array}$ & $\begin{array}{c}.008 \\
(.023)\end{array}$ & $\begin{array}{l}-.044 \\
(.047)\end{array}$ & $\begin{array}{c}.025 \\
(.031)\end{array}$ \\
\hline School attitudes & $\begin{array}{l}-.046^{*} \\
(.019)\end{array}$ & $\begin{array}{l}-.034 * \\
(.014)\end{array}$ & $\begin{array}{l}-.052 \\
(.027)\end{array}$ & $\begin{array}{l}-.038 * \\
(.018)\end{array}$ \\
\hline Missing school attitudes & $\begin{array}{l}1.343 * * \\
(.247)\end{array}$ & $\begin{array}{l}1.040 * * \\
(.164)\end{array}$ & $\begin{array}{l}.748^{*} \\
(.341)\end{array}$ & $\begin{array}{c}.443^{*} \\
(.188)\end{array}$ \\
\hline Work commitment & $\begin{array}{l}.113 * * \\
(.035)\end{array}$ & $\begin{array}{c}.065^{*} \\
(.026)\end{array}$ & $\begin{array}{c}.084 \\
(.051)\end{array}$ & $\begin{array}{c}.048 \\
(.033)\end{array}$ \\
\hline Aversion to using welfare & $\begin{array}{c}.016 \\
(.086)\end{array}$ & $\begin{array}{l}-.057 \\
(.065)\end{array}$ & $\begin{array}{l}-.154 \\
(.129)\end{array}$ & $\begin{array}{l}-.206 * * \\
(.078)\end{array}$ \\
\hline Work/gender role attitudes & $\begin{array}{l}-.034 \\
(.024)\end{array}$ & $\begin{array}{l}-.019 \\
(.019)\end{array}$ & $\begin{array}{c}.015 \\
(.037)\end{array}$ & $\begin{array}{c}.032 \\
(.024)\end{array}$ \\
\hline Influential person's views & $\begin{array}{l}-.024 \\
(.024)\end{array}$ & $\begin{array}{l}-.003 \\
(.019)\end{array}$ & $\begin{array}{l}-.017 \\
(.036)\end{array}$ & $\begin{array}{c}.013 \\
(.021)\end{array}$ \\
\hline Missing views & $\begin{array}{l}-.010 \\
(.244)\end{array}$ & $\begin{array}{l}-.010 \\
(.244)\end{array}$ & $\begin{array}{l}-.561 \\
(.362)\end{array}$ & $\begin{array}{l}-.218 \\
(.220)\end{array}$ \\
\hline Chi-square (df) & $312(33) * *$ & $545(83) * *$ & $366(34) * *$ & $454(84)^{* *}$ \\
\hline
\end{tabular}

${ }^{a}$ Each column of coefficients is from a model that includes the indicated explanatory variables and missing value dummies, family background characteristics, the state welfare guarantee, and a constant. Hazard models also include state and year dummies.

$*$ = significant at 5 percent level.

$* *$ = significant at 1 percent level. 
least by age 25) nor the duration until first receipt of welfare. ${ }^{20}$ Consistent, strong evidence suggests that more positive attitudes toward school lower the likelihood of ever using welfare and increase duration until first receipt. The significant positive relationship between the work commitment index and welfare use that persists in several versions of the model is consistent with the interpretation that higher index values better indicate lower expected wages and earnings prospects than they do a stronger work ethic.

To examine the robustness of these conclusions, we first add the AFQT score to the set of explanatory variables and re-estimate Table 7. Including AFQT tends to weaken the effects, a result consistent with the expectation that part of the influence of attitudes and personality characteristics is transmitted through their effects on academic achievement and, consequently, earnings ability. ${ }^{21} \mathrm{With}$ this expanded specification, the work commitment index is significant only in the "Since Age 15" crosssection logit, and self-esteem is insignificant in all models. The school attitudes index remains significant with a negative coefficient and almost the same magnitude in both "Since Age 15" models, is only marginally significant $(\mathrm{p}=.059)$ in the "Since First Pregnancy" hazard model, and is insignificant in the "Since First Pregnancy" cross-section logit. A new result is that work/gender role attitudes are positively related to welfare use, but only in the "Since First Pregnancy" hazard model. ${ }^{22}$

For a second check, instead of including all attitudes and personality characteristics in the regression, we include each one separately, along with all the other explanatory variables in the models in Table 7. This approach raises the likelihood that any one measure will appear statistically significant. Even so, locus of control and the measure of an influential person's views about nontraditional work still never attain statistical significance. School attitudes are significant in all four models. As in Table 7, work commitment is significant in the two "Since Age 15" models, and the index of aversion to welfare is only significant in the "Since First Pregnancy" hazard model. The major differences between Table 7 and this one-at-a-time approach are for self-esteem and work/gender role attitudes. When entered by 
itself, self-esteem has a negative significant coefficient in three models, and the index of work/gender role attitudes has a negative significant coefficient in two.

These robustness checks confirm the importance of school attitudes, cast some doubt on the finding for the index of work commitment, and confirm that locus of control, aversion to using welfare, and an influential other's attitudes about women's work roles do not affect the likelihood of welfare use or the duration until first receipt of welfare. The one-at-a-time estimates suggest that higher self-esteem and more liberated attitudes about women's work and family roles may reduce welfare use, but the evidence is fragile and little confidence should be placed in these findings.

\section{Impact of Family Background and Personal Characteristics}

Table 8 presents the estimated coefficients on the family background and personal characteristics from the hazard estimates of the full model. The importance of family structure is evident in both models. The "Since Age 15" model suggests that women who spent more of their childhood living with both parents are less likely to use AFDC relative to those living in family structures that do not include the mother. Time living with mother only or mother and stepfather does not significantly affect the chance of AFDC participation relative to the reference family structure. Having more siblings is positively associated with the likelihood of going on AFDC in the "Since First Pregnancy" model. This relationship may result from parental resources of time and money being divided among a larger group of children, which may adversely affect a daughter's early development and chances for future economic success, or later, the ability of the family to help out financially with the daughter's child. The "Since Age 15" results also show that living with a better educated mother or in a home with more educational materials is associated with a smaller likelihood of using AFDC, and living in a poor family raises the likelihood. In the "Since First Pregnancy" model, having a working mother lowers the likelihood of AFDC use and is the only other significant family background factor. 
TABLE 8

Impact of Family Background and Personal Characteristics on Welfare Use: Hazard Model Estimates

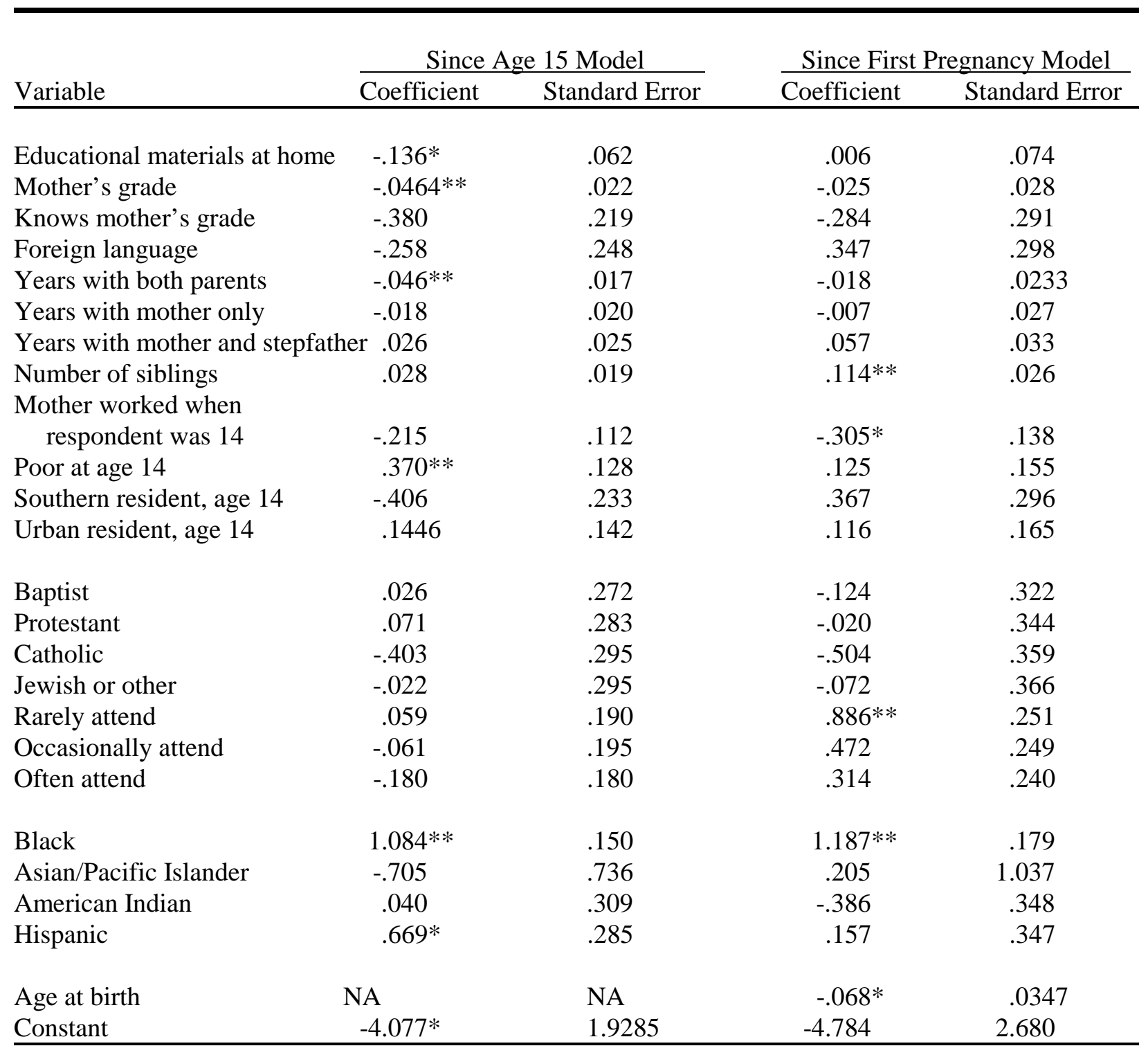

Notes: Reference categories are years lived apart from mother, no religion, never attend services, and white. Models also include the welfare guarantee, state and year dummies, and the attitude and personality variables in Table 7.

$*$ = significant at 5 percent level.

$* *$ = significant at 1 percent level. 
The mostly negative coefficients on the religious upbringing variables suggest that women with a stated childhood religious affiliation tend to be less likely to go on AFDC, but no coefficient is significant at even the 10 percent level. The "Since Age 15" model shows no relationship between attendance at religious services and welfare use. But the "Since First Pregnancy" model finds that women who attend religious services are generally more likely to go on AFDC than those who never attend, though only one of the coefficients is significant (the coefficient on "occasionally attend" is significant at the .06 level).

After controlling for other characteristics, black and Hispanic women are much more likely to participate in AFDC than are women from other racial and ethnic groups. Last, women who were older when they became mothers have lower rates of AFDC participation. Older mothers may be more likely to be married or have stable jobs. ${ }^{23}$

Results for Black, Hispanic, and White Subgroups

Because the extent of welfare use differs substantially among blacks, Hispanics, and whites, and because the relationship between social-psychological characteristics and welfare use may well differ among racial and ethnic groups, we estimated the final model in Table 7 separately for these three groups ${ }^{24}$ Since whites predominate in the overall sample, their results closely resemble those in Table 7. The set of significant coefficients and the signs on those coefficients are identical to those in Table 7, with two exceptions: school attitudes are not significant in the "Since First Pregnancy" hazard model and self-esteem is no longer significant in even one model. Findings for blacks differ from Table 7 in some important ways. None of the school attitudes and work commitment coefficients are significant, even at the .10 level. As in Table 7, the dummy for missing school attitudes has a positive and significant coefficient in all four models, and aversion to welfare has a significant negative coefficient in the "Since First Pregnancy" hazard model. More liberated work and family role attitudes are positively related to 
welfare use in one model. The overall impression from the black estimates is that attitudes and personality characteristics bear virtually no relation to welfare use.

The Hispanic results provide another interesting comparison to Table 7. More liberated attitudes about women's work and family roles are significantly related to less welfare use in three models. This result was masked in regressions on the full sample. School attitudes have significant negative coefficients in all four models (versus three in Table 7), but the dummy for missing school attitudes is insignificant in all four. As for blacks, no work commitment coefficients are significant. Thus, the finding in Table 7 on the work commitment/expected wages index appears to be a reflection of white behavior only. The overall impression from the Hispanic estimates is that school and work/gender role attitudes strongly affect the likelihood and timing of welfare use.

\section{$\underline{\text { Results for Poor versus Nonpoor }}$}

It is often argued that the attitudes and personality characteristics of the poor contribute to their low levels of socioeconomic achievement (e.g., Mead, 1992). To explore whether such characteristics more strongly affect welfare use among the poor, we estimated the final model on the subsample of women who lived in poor families at age 14 and the complementary subsample of those who did not.

The one striking difference between these two groups is in the effect of school attitudes. Among the poor, school attitudes show a significant negative relationship with welfare use in all four models. Among the nonpoor, surprisingly, this variable is insignificant in all four models. For the nonpoor there is weak evidence that more liberated attitudes about women's work and family roles on the part of both the woman and an influential person are related to less welfare use. The positive relationship between the index of work commitment and welfare use observed in Table 7 appears for both groups.

If the poor had much less favorable attitudes toward school than the nonpoor, the greater impact of such attitudes on their outcome would help account for the higher likelihood of welfare use among women raised in poor families. (The percentage reporting having used welfare by age 25 was 39 percent 
for women in the poor subsample and 18 percent for women in the nonpoor subsample.) But the mean value on the school attitudes index is nearly the same for both groups: 31.5 for the poor and 32.0 for the nonpoor. So, though the greater impact implies that women from poor families with less favorable school attitudes would be more likely to use welfare than women with less favorable school attitudes from nonpoor families, it also implies that women from poor families with more favorable school attitudes would be less likely to use welfare than women with more favorable school attitudes from nonpoor families. Thus, the difference in the impact of school attitudes cannot account for the higher likelihood of welfare use among women raised in poor families.

Do Attitudes and Personality Characteristics Mediate the Effects of Personal and Family Background Variables?

Personal and family background variables are significant determinants of the chances of using welfare. Evidence that attitudes and personality characteristics mediate the effects of such variables would provide insight into the mechanisms through which background characteristics influence later experience with welfare. To explore this question, we re-estimated the models in Table 7 excluding all attitude and personality variables. For all four variations, the patterns of significance on the personal and family background characteristics were virtually identical to those in the full models. This suggests that personal and family background variables have weak indirect effects on welfare use transmitted through their influence on social-psychological characteristics. If important indirect effects exist, they operate through variables not included in the model.

\section{DISCUSSION}

Do attitudes and personality characteristics directly affect the likelihood of welfare use or the duration until first receipt of welfare? On the evidence provided by this study's empirical estimates, one would have to answer, "In general, no." The indexes of school attitudes and work commitment are 
exceptions. Young women with more positive school attitudes tend to be less likely to go on welfare. More positive school attitudes plausibly are a harbinger of academic and then labor market success. ${ }^{25}$ Even so, this relationship does not appear for the samples of black women and of women from nonpoor families. Women who express greater willingness to work at low-wage jobs tend to be more likely to go on welfare. This relationship is less robust than the one for school attitudes. The positive relationship suggests that this index is a better indicator of a low expected wage than of an internalized commitment to work. If so, this estimated relationship is more consistent with the economic, rational choice perspective on welfare use than one that posits an important role for attitudes and personality characteristics.

Because the data provide measures of attitudes and personality characteristics prior to teen pregnancy and birth, labor market experience, divorce, AFDC participation, and related demographic and economic events, we think that it likely that we have identified the exogenous effects of these characteristics on welfare participation and not confounded them with the effects of welfare participation on these same characteristics. In view of this and other methodological advantages of the study, the failure to find robust effects of attitudes and personality characteristics reinforces the conventional view among social scientists (if not the general public) that any such effects on economic outcomes are modest and generally insignificant.

Why do the attitude and personality variables have such poor explanatory power? The theoretical discussion points out reasons for expecting both positive and negative coefficients on the measures of work/gender role attitudes and an influential person's views about nontraditional work and, once potential effects on stigma are considered, on the self-esteem and locus of control variables as well. The insignificant estimates for most of these variables in most of the full models are consistent with the possibility that the offsetting positive and negative effects are both important. Nonetheless, this means 
that, over the population of young women, changes in such characteristics are unlikely to have systematic effects on welfare entry.

Another possibility is that, despite other research showing significant relationships between attitudes and personality characteristics and outcomes linked to financial eligibility, such characteristics of the young women in the NLSY do not affect their earnings, the key determinant of financial eligibility. ${ }^{26}$ In that case, decisions about welfare use may be driven largely by economic considerations and their attitudes and personality characteristics may really have little effect. It is also possible that such factors affect economic outcomes, but the effects are minor at the bottom of the ladder (the group most likely to qualify for welfare).

An implicit assumption of our modeling strategy is that the seven social-psychological variables measured early in adolescence remain relatively stable as sample members age into their mid-twenties. Self-esteem and locus of control are often conceived as fairly stable personality attributes that persist through the life span. However, the attitudes may be more mutable for reasons unrelated to welfare use and related economic and demographic events. If so, this could result in measurement error that would help produce insignificant coefficients. Last, though the measures available in the NLSY are not robustly related to welfare use, other attitudes and personality traits may be.

The introduction raised the question: How much control do individuals have over the processes that lead them onto welfare? Mapping causation (some would say "blame") to individual, family, and societal influences is complicated by data limitations. Better measures of local economic and social conditions could tease out a larger role for that sphere (and less for family characteristics). Some variables we have grouped with family background characteristics (e.g., race, residence) are likely to be proxies for these economic and social conditions and to have major influences on the social opportunities open to a young woman. 
These caveats duly noted, the estimates reported here imply that family background and broader social conditions — conditions beyond a young woman's control—play more fundamental roles than her attitudes, self-esteem, and locus of control in determining her chances of being on welfare. Though six of the seven social-psychological factors show a relationship to welfare receipt, the correlations are largely spurious since most of the relationships disappear after controlling for family background and social context. Whether individuals can "control" these attitudes and personality characteristics is another issue we will not take up. Since most of them do not seem to matter, we do not need to answer this question to conclude that this study's evidence is consistent with structuralist explanations of welfare use.

To receive welfare a woman must have had a child, usually be unmarried or divorced, and have low income and few assets. Recent public debates about welfare have centered around the questions of individual responsibility for these states and whether policies could sway those outcomes. Will young women be less likely to get pregnant (or have additional children) if welfare benefits are lower? Will time limits on welfare receipt prompt women to have fewer children or to work harder to find a job? Will work requirements induce more welfare recipients to work their way off welfare? Could child support enforcement and the lack of easy welfare receipt lower nonmarital childbearing and make divorce less attractive to men? The power of the policy levers rests in the assumption that many welfare recipients have control over these processes and will alter behaviors and outcomes in response to changes. Other welfare policies have targeted the intergenerational issues of welfare- that is, the family role in the path to welfare. Some states have adopted laws requiring welfare families to live with parents, limit school absences, and vaccinate children, or holding parents responsible for the costs of welfare for their children and grandchildren. These policies are predicated on the assumption that families can mold opportunities for their children.

Policies targeting individuals and families could affect welfare rolls and the costs to government, but our results suggest that they will not succeed via changes in self-esteem and other attitudes or 
personality characteristics. Interventions aimed specifically at altering attitudes and personality characteristics are unlikely to affect welfare participation. 


\section{APPENDIX}

\section{Items Used to Construct the Attitude and Personality Variables}

\section{Self-esteem items, scored on a four-point Likert scale}

1. I feel that I'm a person of worth, at least on an equal basis with others.

2. I feel that I have a number of good qualities.

3. All in all, I am inclined to feel that I am a failure.

4. I am able to do things as well as most other people.

5. I feel I do not have much to be proud of.

6. I take a positive attitude toward myself.

7. On the whole, I am satisfied with myself.

8. I wish I could have more respect for myself.

9. I certainly feel useless at times.

10. At times I think I am no good at all.

The index ranges from 10 to 40 ; reliability $=.82$.

\section{Rotter locus of control scale items}

The four items are the following pairs of statements. Each respondent selects which statement is closer to her opinion and then indicates whether it is much closer or slightly closer. This yields four possible sets of responses, coded from one to four, with one for the pair of responses indicative of the more external locus of control.

1. What happens to me is my own doing, or

Sometimes I feel that I don't have enough control over the direction my life is taking.

2. When I make plans, I am almost certain that I can make them work, or It is not always wise to plan too far ahead, because many things turn out to be a matter of good or bad fortune anyhow.

3. In my case, getting what I want has little or nothing to do with luck, or Many times we might just as well decide what to do by flipping a coin. 
4. Many times I feel that I have little influence over the things that happen to me, or It is impossible for me to believe that chance or luck plays an important role in my life.

The index ranges from 4 to 16 ; reliability $=.22$.

School attitude items, scored on a four-point Likert scale

1. Most of the teachers are willing to help with personal problems.

2. Most of my classes are boring.

3. This school offers good job counseling.

4. Most of my teachers really know their subjects well.

5. You can get away with almost anything at this school.

6. My schoolwork requires me to think to the best of my ability.

7. At this school, a person has the freedom to learn what interests him or her.

8. How satisfied are you with your school—very satisfied, somewhat satisfied, somewhat dissatisfied, or very dissatisfied?

9. It's easy to make friends at this school.

10. I don't feel safe at school.

The index ranges from 10 to 40 ; reliability $=.66$.

\section{Aversion to welfare items}

Suppose at age 35 you and your (husband/wife) could not earn enough money by working to support your family; please tell me whether you probably would or probably would not do each of the following:

1. Go on welfare

2. Apply for food stamps

The index ranges from 2 to $4(1=$ probably would; $2=$ probably would not $)$; reliability $=.52$. 
Work commitment items are yes/no responses to hypothetical job offers

If next summer you were offered a full-time job at $\$ 2.50$ an hour do you think you would accept it if it were

1. washing dishes

2. working in a factory

3. working as a cleaning person

4. working at a check-out counter in a supermarket

5. cleaning up neighborhoods

6. working at a hamburger place

7. working away from home in a national forest or park

The index ranges from 0 to 7 ; reliability $=.73$.

Women's work and family roles attitude items, scored on a four-point Likert scale

1. A woman's place is in the home, not in the office or shop.

2. A wife who carries out her full family responsibilities doesn't have time for outside employment.

3. The employment of wives leads to more juvenile delinquency.

4. It is much better for everyone concerned if the man is the achiever outside the home and the woman takes care of the home and family.

5. Men should share the work around the house with women, such as doing dishes, cleaning, and so forth.

6. Women are much happier if they stay at home and take care of their children.

The index ranges from 6 to 24 ; reliability $=.72$.

\section{Items for attitudes of an influential person about nontraditional jobs and family roles}

We would like to ask you what your (relationship) would think if you decided to

1. be a carpenter

2. join the armed forces 
3. be an accountant

4. become an electrical engineer

5. never have children

6. pursue a full-time career

7. delay starting a family

The index ranges from 6 to 24 ; reliability $=.64$. 


\section{APPENDIX TABLE 1}

Correlations among Attitudes and Personality Characteristics

(Sample Size Shown under Correlation Coefficient)

\begin{tabular}{|c|c|c|c|c|c|c|}
\hline & $\begin{array}{c}\text { Locus } \\
\text { of Control } \\
\end{array}$ & $\begin{array}{c}\text { School } \\
\text { Attitudes }\end{array}$ & $\begin{array}{c}\text { Work } \\
\text { Commitment } \\
\end{array}$ & $\begin{array}{c}\text { Aversion to } \\
\text { Using Welfare }\end{array}$ & $\begin{array}{l}\text { Work/Gender } \\
\text { Role Attitudes }\end{array}$ & $\begin{array}{c}\text { Influential } \\
\text { Person's Views }\end{array}$ \\
\hline Self-esteem & $\begin{array}{c}-.223 * * \\
2023\end{array}$ & $\begin{array}{l}.173 * * \\
2023\end{array}$ & $\begin{array}{c}-.115^{* *} \\
2014\end{array}$ & $\begin{array}{l}.137 * * \\
1926\end{array}$ & $\begin{array}{l}.217 * * \\
1954\end{array}$ & $\begin{array}{l}.123 * * \\
2023\end{array}$ \\
\hline Locus of control & & $\begin{array}{c}-.083^{* *} \\
2080\end{array}$ & $\begin{array}{c}-.150^{* *} \\
2072\end{array}$ & $\begin{array}{l}.179^{* *} \\
1983\end{array}$ & $\begin{array}{c}-.126^{* *} \\
2016\end{array}$ & $\begin{array}{l}.141^{* *} \\
2080\end{array}$ \\
\hline School attitudes & & & $\begin{array}{l}.055^{*} \\
2098\end{array}$ & $\begin{array}{l}.073 * * \\
2004\end{array}$ & $\begin{array}{l}-.001 \\
2037\end{array}$ & $\begin{array}{l}.057 * * \\
2108\end{array}$ \\
\hline Work commitment & & & & $\begin{array}{l}-.035 \\
1997\end{array}$ & $\begin{array}{c}-.046^{*} \\
2030\end{array}$ & $\begin{array}{l}.027 \\
2098\end{array}$ \\
\hline Aversion to using welfare & & & & & $\begin{array}{l}.195^{* *} \\
1956\end{array}$ & $\begin{array}{l}.043 \\
2004\end{array}$ \\
\hline Work/gender role attitudes & & & & & & $\begin{array}{l}.190 * * \\
2037\end{array}$ \\
\hline
\end{tabular}

\footnotetext{
$*=$ significant at 5 percent level (two-tailed test).

** = significant at 1 percent (two-tailed test).
} 


\section{Endnotes}

${ }^{1}$ Also, since most analyses of socioeconomic outcomes based on micro-data report R-squares in the $0.2-0.3$ range and omit attitudes and personality characteristics, considerable unaccounted explanatory power might reside in such variables.

${ }^{2}$ Boisjoly, Harris, and Duncan (1996) examine trends in the number and duration of initial welfare spells, and in events and demographic characteristics associated with the start of an initial spell. They do not estimate multivariate models of duration until the start of an initial spell. Studies of caseload dynamics based on aggregate case data from administrative sources (e.g., Albert, 1988) cannot analyze the role of individual characteristics.

${ }^{3}$ In any case, since samples for studies of re-entry necessarily consist of former welfare recipients, a small and endogenously selected subset of all women who might initially enter welfare, determinants of re-entry are likely to differ from those of an initial spell.

${ }^{4}$ See Moffitt (1992) for a review of pre-1992 work. Bane and Ellwood (1994), Blank and Ruggles (1996), Fitzgerald (1995), Harris (1993), Hoynes and MaCurdy (1994), Pavetti (1993), and Petersen (1995) are more recent studies.

${ }^{5}$ Goodban (1985) also studies psychological consequences of welfare, but since her data are cross-sectional and she only provides descriptive statistics, little confidence can be placed in the findings. See Schneiderman, Furman, and Weber (1989) for further discussion of earlier work on the relationship between self-esteem and welfare use.

${ }^{6} \mathrm{We}$ broadly conceive the social environment to include peer groups, neighborhood characteristics and institutions (e.g., churches), media, and aspects of popular culture, all of which may affect the development of attitudes and personality traits and, later in life, socioeconomic outcomes that help determine eligibility for welfare.

${ }^{7}$ During the period we analyze, 1978-1991, many states operated the AFDC-Unemployed Parent 
(AFDC-UP) program, which provided cash welfare for two-parent families. However, because participation in the AFDC-UP program was limited by stringent rules regarding previous employment, nearly every woman on welfare was an unmarried parent (U.S. House of Representatives, 1996, p. 467).

${ }^{8}$ The personality characteristics mentioned here are those available in the NLSY.

${ }^{9}$ For example, a teen doing poorly academically may develop poorer attitudes toward school and have lower self-esteem and a more external locus of control.

${ }^{10} \mathrm{We}$ observe only three spells of welfare that began on or before a respondent turned 15 .

${ }^{11}$ In the Cox proportional hazard model, the explanatory factors shift the level of the hazard function, but the underlying shape of the function over time is assumed to be stable and is not estimated (Yamaguchi, 1991). Sample sizes for the hazard models are slightly higher than for the logit models because they do not require complete data through age 25 . A woman may never be observed to receive AFDC because she has not reported receiving AFDC by the end of the sample period (December 1991), or she may have missing data because of nonreporting or attrition, in which case her spell is censored.

${ }^{12}$ When the sample includes all women, the entry and participation-by-25 models provide reduced form estimates since each explanatory variable's coefficient reflects its net impact on childbearing, marital and labor market decisions, and participation conditional on categorical and financial eligibility. When the sample conditions on having a child, the models are semi-reduced form since coefficients reflect impacts on marital and labor market decisions as well as participation. Since these outcomes may well be jointly determined, the fully reduced form model is less likely to be biased.

${ }^{13}$ Rebecca Maynard (personal communication, 1997) reports about a 60 percent underreporting of AFDC receipt by teen parents under age 18. To get a sense of how much underreporting there might be, we divided women who became mothers by age 18 into three groups: (1) those who reported first use of AFDC on or before age 18, (2) those who reported first use between 18 and 19, and (3) those who either never received AFDC or reported first receipt at an age greater than 19. Women who became mothers 
before 18 comprise 24.5 percent of all mothers in the sample. Shares of groups A, B, and C are 5.5, 5.8, and 13.2 percent. Though women in group A may not have reported all months of AFDC use, it is unlikely they underreported very much. Some women in group B may have been receiving AFDC before 18 but may only have begun reporting it as their own AFDC once they became legal adults, so women in this group would seem to be most likely to have underreported early welfare use. Fortunately, this group accounts for a small portion of all mothers in our data. Some women in group C may have behaved the same way, but this would seem less likely and becomes increasingly less likely the longer the time between having a birth and reporting first use. (For group C, mean duration between becoming demographically eligible and either reporting first use or being censored is 8.2 years; only 10 percent waited 3 years or less before reporting AFDC receipt.) However, some members of group C may have received AFDC before 18 and not reported it, and then either never received it after age 18 or never reported later use. So some unknown but probably small portion of group C did not report early welfare use.

${ }^{14}$ The NLSY lacks information on other similar characteristics that might also belong in a comprehensive study of social-psychological influences on welfare based on problem behavior theory or other broad theories of social behavior.

${ }^{15}$ The minimum wage in 1979 was $\$ 2.90$. We constructed parallel indices for responses to the same questions, but at a wage of $\$ 3.50$ or $\$ 5.00$ (\$7.56 and \$10.80 in 1996 dollars). Estimation results were the same using these alternatives.

${ }^{16}$ See Rank and Hirschl (1993) for evidence of such an effect for food stamp participation.

${ }^{17} \mathrm{We}$ sum the dummies because correlation among these three indicators (between .24 and .33 ) led to unstable results when they were included separately.

${ }^{18} \mathrm{We}$ omit a measure for receipt of welfare during the respondent's teen years since it is strongly correlated $(r=.48)$ with poverty status. 
${ }^{19}$ Benefit levels are for a family of four. Medicaid benefits are measured by average state spending on Medicaid per eligible family. Benefit values are adjusted using the Consumer Price Index with 1982 as base year. We thank Robert Moffitt for providing the welfare policy data. We also ran models with alternative measures of the guarantee and with additional indicators of welfare policy such as the presence of the AFDC-UP program, which was state-optional during most of the period we analyze. Results for the attitude and personality variables were insensitive to such variations.

${ }^{20}$ Only if the correct behavioral model is the one implicit in Table 5, in which family background affects welfare use only indirectly via its influence on attitudes and personality characteristics, can one conclude that attitudes and personality characteristics affect welfare use. There is little reason to accept this model.

${ }^{21}$ In a simple ordinary least squares regression of AFQT on only the seven social-psychological characteristics, the $\mathrm{R}^{2}$ is .21 ; six characteristics are significant at the .001 level, and one at the .06 level.

${ }^{22}$ In all four models AFQT has a strongly significant negative relationship to welfare use.

${ }^{23}$ The cross-section logit "Since First Pregnancy" model has the same significant variables with the same coefficient signs as in Table 8. Results for the cross-section logit "Since Age 15" model are nearly the same as in Table 8 except the coefficient on number of siblings is significant $(p=.006)$, the ones on the poverty status and Catholic variables are only marginally significant ( $\mathrm{p}=.07$ and .06$)$, and the one on southern resident is significant $(\mathrm{p}=.003)$. The last difference clearly arises because the crosssection model omits state effects. Finally, in all four models the welfare guarantee is not significant.

${ }^{24}$ In our sample, for example, the percentage reporting having used welfare by age 25 was 43,21 , and 12 percent for blacks, Hispanics, and whites. There were far too few Asian/Pacific Islanders and American Indians in the NLSY to allow separate estimates.

${ }^{25}$ However, academic success may well affect school attitudes or the two may be jointly determined by other factors. If so, the findings on school attitudes may suffer from endogeneity bias. 
${ }^{26}$ The wage models in Goldsmith et al. (1997) pool men and women. Would self-esteem and locus of control be significant in wage regressions restricted to women? If they were, they might still not be significantly related to earnings if they are not related to hours of work. The evidence in Duncan et al. (1996) that noncognitive traits affect wages is only for men. 


\section{References}

Albert, Vicky N. 1988. Welfare Dependence and Welfare Policy: A Statistical Study. New York: Greenwood Press.

Allin, Susan, and Harold Beebout. 1989. "Determinants of Participation in the Food Stamp Program: A Review of the Literature." Report submitted to U.S. Department of Agriculture, Food and Nutrition Service. Washington, DC: Mathematica Policy Research.

Andrisani, P. J. 1977. "Internal-External Attitudes, Personal Initiative, and the Labor Market Experience of Black and White Men." Journal of Human Resources 12: 308-328.

Bane, Mary Jo, and David T. Ellwood. 1994. Welfare Realities: From Rhetoric to Reform. Cambridge, MA: Harvard University Press.

Bassi, Laurie J. 1990. "Employment and Welfare Participation among Women.” Economic Inquiry 28: 222-238.

Besley, Timothy, and Stephen Coate. 1992. "Understanding Welfare Stigma: Taxpayer Resentment and Statistical Discrimination." Journal of Public Economics 48: 165-183.

Blank, Rebecca M., and Patricia Ruggles. 1994. "Short-Term Recidivism among Public-Assistance Recipients." American Economic Review 84(2): 49-53.

1996. "When Do Women Use Aid to Families with Dependent Children and Food Stamps?:

The Dynamics of Eligibility versus Participation.” Journal of Human Resources 31: 57-89.

Boisjoly, Johanne, Kathleen M. Harris, and Greg Duncan. 1996. "Initial Welfare Spells: Trends, Events, and Duration, with Implications for Welfare Reform.” Working Paper 96-22, Institute for Policy Research, Northwestern University.

Brandon, Peter D. 1995. "Vulnerability to Future Dependence among Former AFDC Mothers." Discussion Paper no. 1055-95, Institute for Research on Poverty, University of Wisconsin-Madison.

Clarkberg, Marin, Ross Stolzenberg, and Linda Waite. 1995. "Attitudes, Values, and Entrance into Cohabitational versus Marital Unions.” Social Forces 74: 609-632.

Corcoran, Mary, Greg Duncan, Gerald Gurin, and Patricia Gurin. 1985. "Myth and Reality: The Causes and Persistence of Poverty." Journal of Policy Analysis and Management 4: 516-536.

Dolinsky, Arthur, Richard Caputo, and Patrick O'Kane. 1989. "Competing Effects of Culture and Situation on Welfare Receipt.” Social Service Review 63 (September): 359-371.

Duncan, Greg, Rachel Dunifon, and Dave Knutson. 1996. "Vim Will Win: Long Run Effects of Motivation and Other 'Noncognitive' Traits on Success." Working Paper 96-23, Institute for Policy Research, Northwestern University. 
Duncan, Greg, and Saul Hoffman. 1990. "Welfare Benefits, Economic Opportunities, and Out-ofWedlock Births among Black Teenage Girls.” Demography 27: 519-535.

Duncan, Greg, and James N. Morgan. 1981. "Sense of Efficacy and Subsequent Change in Earnings—A Replication." Journal of Human Resources 16: 649-657.

Eagly, Alice H., and Shelly Chaiken. 1993. The Psychology of Attitudes. Fort Worth: Harcourt Brace Jovanovich College Publishers.

Elliott, Marta. 1996. "Impact of Work, Family, and Welfare Receipt on Women's Self-Esteem in Young Adulthood." Social Psychology Quarterly 59: 80-95.

Esterberg, Kristin G., Phyllis Moen, and Donna Dempster-McCain. 1994. "Transition to Divorce: A LifeCourse Approach to Women's Marital Duration and Dissolution." Sociological Quarterly 35: 289-307.

Fitzgerald, John. 1995. "Local Labor Markets and Local Area Effects on Welfare Duration.” Journal of Policy Analysis and Management 14: 43-67.

Gleason, Phillip, Anu Rangarajan, and Peter Schochet. N.d. "The Dynamics of AFDC Spells among Teenage Parents.” Princeton, NJ: Mathematica Policy Research.

Goldsmith, Arthur, Jonathan Veum, and William Darity. 1997. "The Impact of Psychological and Human Capital on Wages.” Economic Inquiry 35: 815-829.

Goodban, Nancy. 1985. “The Psychological Impact of Being on Welfare.” Social Service Review 59: 403-422.

Goodwin, Leonard. 1983. Causes and Cures of Welfare: New Evidence on the Social Psychology of the Poor. Lexington, MA: Lexington Books.

Gottschalk, Peter. 1996. "Is the Correlation in Welfare Participation across Generations Spurious?" Journal of Public Economics 63: 1-25.

Gottschalk, Peter, and Robert Moffitt. 1994. "Welfare Dependence: Concepts, Measures, and Trends." American Economic Review 84(2): 38-42.

Gritz, R. Mark, and Thomas MaCurdy. 1991. Patterns of Welfare Utilization and Multiple Program Participation among Young Women. Report to the U.S. Department of Health and Human Services.

Harris, Kathleen M. 1993. "Work and Welfare among Single Mothers in Poverty." American Journal of Sociology 99: 317-352. 1996. "Life after Welfare: Women, Work, and Repeat Dependency." American Sociological Review 61: 407-426.

1997. Teen Mothers and the Revolving Welfare Door. Philadelphia: Temple University Press. 
Haveman, Robert, and Barbara Wolfe. 1994. Succeeding Generations: On the Effects of Investments in Children. New York: Russell Sage Foundation.

Hoynes, Hilary, and Thomas MaCurdy. 1994. "Has the Decline in Benefits Shortened Welfare Spells?" American Economic Review 84(2): 43-48.

Hutchens, Robert. 1981. "Entry and Exit Transitions in a Government Transfer Program: The Case of Aid to Families with Dependent Children." Journal of Human Resources 16: 217-237.

Jessor, Richard, and Shirley Jessor. 1977. Problem Behavior and Psychosocial Development: A Longitudinal Study of Youth. New York: Academic Press.

Kaplan, Howard. 1975. Self-Attitudes and Deviant Behavior. Pacific Palisades, CA: Goodyear Publishing Co.

Lane, Julia, and David Stevens. 1995. "Family, Work, and Welfare History: Work and Welfare Outcomes.” American Economic Review 85(2): 266-270.

McLanahan, Sara. 1988. "Family Structure and Dependency: Early Transitions to Female Household Headship." Demography 25: 1-16.

Mead, Lawrence. 1992. The New Politics of Poverty: The Nonworking Poor in America. New York: Basic Books.

Moffitt, Robert. 1983. “An Economic Model of Welfare Stigma.” American Economic Review 73: 1023-1035.

_ 1992. "Incentive Effects of the U.S. Welfare System: A Review." Journal of Economic Literature 30: 1-61.

1994. "Welfare Effects on Female Headship with Area Effects." Journal of Human Resources 29: 621-636.

Moore, Kristin, Brent Miller, Dana Glei, and Donna Morrison. 1995. Adolescent Sex, Contraception, and Childbearing: A Review of Recent Research. Washington, DC: Child Trends, Inc.

Neal, Derek, and William Johnson. 1996. "The Role of Premarket Factors in Black-White Wage Differences." Journal of Political Economy 104: 869-895.

Nichols-Casebolt, Ann. 1986. "The Psychological Effects of Income Testing Income-Support Benefits." Social Service Review 60: 287-302.

O'Neill, June A., Laurie J. Bassi, and Douglas A. Wolf. 1987. "The Duration of Welfare Spells." Review of Economics and Statistics 69: 241-248.

Osterman, Paul. 1991. "Welfare Participation in a Full Employment Economy: The Impact of Neighborhood." Social Problems 38: 475-491. 
Parcel, Toby L., and Charles W. Mueller. 1983. Ascription and Labor Markets: Race and Sex Differences in Earnings. New York: Academic Press.

Pavetti, LaDonna. 1993. "The Dynamics of Welfare and Work: Exploring the Process by Which Young Women Work Their Way off Welfare.” Ph.D. dissertation, Kennedy School of Government, Harvard University.

Petersen, Carol. 1995. "Female-Headed Families on AFDC: Who Leaves Welfare Quickly and Who Doesn't?" Journal of Economic Issues 29: 619-628.

Plotnick, Robert. 1983. "Turnover in the AFDC Population: An Event History Analysis.” Journal of Human Resources 18: 65-81.

1992. "The Effects of Attitudes on Teenage Premarital Pregnancy and Its Resolution." American Sociological Review 57: 800-811.

Rainwater, Lee. 1982. "Stigma in Income Tested Programs." In Income-Tested Transfer Programs, edited by Irwin Garfinkel. New York: Academic Press. Pp. 19-46.

Rank, Mark. 1986. "Family Structure and the Process of Exiting from Welfare." Journal of Marriage and the Family 48: 607-618.

Rank, Mark, and Thomas Hirschl. 1993. "The Link Between Population Density and Welfare Participation.” Demography 30: 607-622.

Rosenberg, Morris. 1990. "The Self-Concept, Social Product and Social Forces." In Social Psychology: Sociological Perspectives, edited by M. Rosenberg and R. Turner. New Brunswick, NJ: Transaction Publishers. Pp. 593-624.

Schneiderman, Leonard, Walter M. Furman, and Joseph Weber. 1989. "Self-Esteem and Chronic Welfare Dependency." In The Social Importance of Self-Esteem, edited by Andrew Mecca, Neil Smelser, and John Vasconcellos. Berkeley, CA: University of California Press. Pp. 200-247.

Solon, Gary, Mary Corcoran, Roger Gordon, and Deborah Laren. 1988. "Sibling and Intergenerational Correlations in Welfare Program Participation." Journal of Human Resources 23: 388-396.

Szekelyi, Maria, and Robert Tardos. 1993. "Attitudes That Make a Difference: Expectancies and Economic Progress.” Discussion Paper no. 1003-93, Institute for Research on Poverty, University of Wisconsin-Madison.

U.S. House of Representatives, Committee on Ways and Means. 1996. Green Book. Background Material and Data on Programs within the Jurisdiction of the Committee on Ways and Means. Washington, DC: U.S. Government Printing Office.

Wilson, William J. 1996. When Work Disappears: The World of the New Urban Poor. New York: Alfred A. Knopf.

Yamaguchi, Kazuo. 1991. Event History Analysis. Newbury Park, CA: Sage Publications. 